Atmos. Chem. Phys., 18, 16253-16269, 2018

https://doi.org/10.5194/acp-18-16253-2018

(C) Author(s) 2018. This work is distributed under

the Creative Commons Attribution 4.0 License.

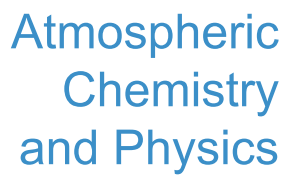

(c) (P)

\title{
Using CALIOP to constrain blowing snow emissions of sea salt aerosols over Arctic and Antarctic sea ice
}

\author{
Jiayue Huang, Lyatt Jaeglé, and Viral Shah \\ Department of Atmospheric Sciences, University of Washington, Seattle, WA, USA
}

Correspondence: Lyatt Jaeglé (jaegle@uw.edu)

Received: 21 March 2018 - Discussion started: 7 May 2018

Revised: 23 October 2018 - Accepted: 25 October 2018 - Published: 16 November 2018

\begin{abstract}
Sea salt aerosols (SSA) produced on sea ice surfaces by blowing snow events or the lifting of frost flower crystals have been suggested as important sources of SSA during winter over polar regions. The magnitude and relative contribution of blowing snow and frost flower SSA sources, however, remain uncertain. In this study, we use 2007-2009 aerosol extinction coefficients from the Cloud-Aerosol Lidar with Orthogonal Polarization (CALIOP) instrument onboard the Cloud-Aerosol Lidar and Infrared Pathfinder Satellite Observation (CALIPSO) satellite and the GEOS-Chem global chemical transport model to constrain sources of SSA over Arctic and Antarctic sea ice. CALIOP retrievals show elevated levels of aerosol extinction coefficients (10$\left.20 \mathrm{Mm}^{-1}\right)$ in the lower troposphere $(0-2 \mathrm{~km})$ over polar regions during cold months. The standard GEOS-Chem model underestimates the CALIOP extinction coefficients by $50 \%-$ $70 \%$. Adding frost flower emissions of SSA fails to explain the CALIOP observations. With blowing snow SSA emissions, the model captures the overall spatial and seasonal variation of CALIOP aerosol extinction coefficients over the polar regions but underestimates aerosol extinction over Arctic sea ice in fall to early winter and overestimates winter-tospring extinction over Antarctic sea ice. We infer the monthly surface snow salinity on first-year sea ice required to minimize the discrepancy between CALIOP extinction coefficients and the GEOS-Chem simulation. The empirically derived snow salinity shows a decreasing trend between fall and spring. The optimized blowing snow model with inferred snow salinities generally agrees with CALIOP extinction coefficients to within $10 \%$ over sea ice but underestimates them over the regions where frost flowers are expected to have a large influence. Frost flowers could thus contribute indirectly to SSA production by increasing the local surface snow salin-
\end{abstract}

ity and, therefore, the SSA production from blowing snow. We carry out a case study of an Arctic blowing snow SSA feature predicted by GEOS-Chem and sampled by CALIOP. Using back trajectories, we link this feature to a blowing snow event that occurred 2 days earlier over first-year sea ice and was also detected by CALIOP.

\section{Introduction}

Sea salt aerosols (SSA) are produced via wave breaking in the open ocean (Lewis and Schwartz, 2004; De Leeuw et al., 2011, and references therein). Over polar regions, SSA can also be generated via sublimation of saline blowing snow (Simpson et al., 2007; Yang et al., 2008), wind-blown frost flower crystals (Rankin et al., 2000; Domine et al., 2004; $\mathrm{Xu}$ et al., 2013), and by leads in sea ice (Nilsson et al., 2001; May et al., 2016). SSA production from blowing snow events requires strong winds $\left(>7 \mathrm{~m} \mathrm{~s}^{-1}\right)$ and depends on the salinity of snow cover on sea ice (Yang et al., 2008). Frost flowers grow over new sea ice formed from open leads under low ambient temperatures $\left(<-20^{\circ} \mathrm{C}\right.$; Kaleschke et al., 2004). These two sea ice sources of SSA have been proposed to help explain polar observations of wintertime maxima in SSA mass concentrations (Wagenbach et al., 1998; Weller et al., 2008; Jourdain et al., 2008; Udisti et al., 2012; Huang and Jaeglé, 2017), the depletion of sulfate-to-sodium mass ratio in winter SSA relative to bulk sea water at sites in Antarctica (Wagenbach et al., 1998; Rankin et al., 2000; Jourdain et al., 2008; Hara et al., 2012) and some sites in the Arctic (Jacobi et al., 2012; Seguin et al., 2014) as well as the increase in $\mathrm{Na}^{+}$deposition fluxes during glacial periods relative to 
interglacial periods (Wolff et al., 2006; Fischer et al., 2007; Abram et al., 2013).

In a previous study (Huang and Jaeglé, 2017), we used the GEOS-Chem chemical transport model to examine the relative roles of blowing snow and frost flowers as sources of polar SSA during winter. Our study was based on the blowing snow parameterization developed by Yang et al. (2008) and the frost flower parameterization of $\mathrm{Xu}$ et al. (2013). We compared our simulations to in situ observations of SSA mass concentrations at three surface sites in the Arctic and two sites in coastal Antarctica, showing that blowing snow appeared to be the dominant source of polar SSA during winter. Here, we further constrain the spatial and temporal distribution of polar sources of SSA by using observations of aerosol extinction coefficients from the Cloud-Aerosol Lidar with Orthogonal Polarization (CALIOP) instrument onboard the Cloud-Aerosol Lidar and Infrared Pathfinder Satellite Observations (CALIPSO) satellite together with the GEOSChem model.

One of the main uncertainties in estimating blowing snow emissions is the salinity of surface snow on sea ice. In our previous work (Huang and Jaeglé, 2017), we assumed constant surface snow salinity over Arctic (0.1 practical salinity unit, or psu) and Antarctic (0.03 psu) sea ice. In reality, surface snow salinity is highly variable in time and space. The sources of sea salt in snow over sea ice include the upward migration of brine from the sea ice surface, incorporation of frost flowers, and SSA deposition from the nearby open ocean (Domine et al., 2004). Initial sea ice formation is accompanied by upward salt transport, such that first-year sea ice (FYI) has a high salinity, reaching 20-100 psu at the sea ice surface (Weeks and Lee, 1958; Martin, 1979; Weeks and Ackley, 1986). Nakawo and Sinha (1981) found that sea ice salinity decreases rapidly within the first week of sea ice formation in fall, and then decreases more slowly between December and May in the Canadian Arctic. Worby et al. (1998) showed that ice with a thickness of less than $0.05 \mathrm{~m}$ displayed salinities of 9-28 psu, while ice thicker than $0.05 \mathrm{~m}$ had salinities of 4-8 psu, which decreased linearly with ice thickness. As snow accumulates on FYI throughout winter, the brine is wicked upward, resulting in brine-wetted snow (Barber et al., 1995). Snow salinity is highest in the first $10 \mathrm{~cm}$ above FYI, with values of 1-20 psu (Geldsetzer et al., 2009), and then decreases rapidly as the snow cover gets thicker, with low salinities on the surface of thick snow (Nandan et al., 2017). Older and thicker multiyear sea ice (MYI), is desalinated by flushing and gravity drainage during repeated summer melt cycles, such that the overlaying snow has very low salinity. Krnavek et al. (2012) reported that surface snow salinity sampled on MYI was $0.01 \mathrm{psu}$, compared to $0.1 \mathrm{psu}$ for snow on thick FYI and 0.8 psu on recently frozen thin FYI in March near Barrow, Alaska.

The role of frost flowers as a direct source of SSA remains subject to debate. Some studies have shown that strong winds inhibit frost flower formation and bury existing frost flowers with snow (Perovich and Richeter-Menge, 1994; Rankin et al., 2000), while field experiments show that frost flowers are difficult to break (Domine et al., 2005; Alvarez-Avilez et al., 2008; Obbard et al., 2009). In addition, laboratory experiments show that evaporating frost flowers form a cohesive chunk of salt (Yang et al., 2017), which is unlikely to be a direct source of SSA, even when exposed to large wind speeds (Roscoe et al., 2011).

In this study, we use 3 years (2007-2009) of CALIOP aerosol extinction coefficients to constrain the spatial and temporal distribution of polar SSA emissions with the GEOS-Chem model. Satellite observations and GEOS-Chem simulations are described in Sect. 2. In Sect. 3, we evaluate the model's ability to reproduce observed aerosol extinction over the Arctic and Antarctic sea ice regions with and without sea ice sources of SSA. In Sect. 4, we develop an empirical parameterization of seasonally varying surface snow salinity on FYI. In Sect. 5, we conduct a case study of an Arctic blowing snow event and the resulting SSA observed by CALIOP.

\section{Observations and model simulations}

\subsection{CALIOP observations of aerosol extinction coefficients}

The CALIOP lidar measures backscatter signals of optical pulses at 532 and $1064 \mathrm{~nm}$ (Winker et al., 2009). CALIOP samples the optical properties of clouds and aerosols during daytime and nighttime with a 16-day repeat cycle. It has a horizontal sampling resolution of $335 \mathrm{~m}$ and a vertical sampling resolution of $30 \mathrm{~m}$ below $30-40 \mathrm{~km}$ altitude. In this study, we use vertical profiles of $532 \mathrm{~nm}$ aerosol extinction from CALIOP Level 2 (L2) version 4.10 profile data for 2007-2009 (Winker, 2016). L2 data are retrieved with a set of algorithms, which identify the cloud and aerosol layers and classify their feature types (Liu et al., 2009). Extinctionto-backscatter ratios (lidar ratios) are assigned based on the aerosol types for calculations of L2 aerosol extinction (Omar et al., 2009). Tesche et al. (2014) showed that CALIOP v3.01 aerosol extinction coefficients overestimated in situ observations in the Arctic by $47 \%$. For the version 4.10 product, a new subtype, "dusty marine", is assigned when dust and marine aerosols coexist, with a lidar ratio $33 \%$ smaller than that of polluted dust (Winker, 2016), which brings the in situ and CALIOP extinction coefficients in closer agreement (not shown). The layer detection algorithm is performed downward for single shots, and profiles are averaged horizontally at $1,5,20$, and $80 \mathrm{~km}$ to achieve a good signal-to-noise-ratio (SNR) for aerosol retrievals (Winker et al., 2009). The estimated detection sensitivity of the CALIOP $532 \mathrm{~nm}$ channel varies with different horizontal averaging, with better sensitivity at larger horizontal averaging $(80 \mathrm{~km})$. Nighttime CALIOP extinction coefficients have better sensitivity than 
daytime observations, which are affected by noise from solar radiation scattering (Winker et al., 2009).

We average monthly CALIOP L2 aerosol extinction profiles poleward of $60^{\circ}$ over a $2^{\circ}$ latitude by $5^{\circ}$ longitude horizontal grid in $60 \mathrm{~m}$ vertical bins, using the same approach as Winker et al. (2013). When no aerosols are detected and the layer is classified as "clear air", we assign it an extinction coefficient value of $0.0 \mathrm{~km}^{-1}$. Following Winker et al. (2013), we exclude the following aerosol layers from our gridded averages: (1) all aerosol layers within $60 \mathrm{~m}$ of the surface to avoid surface contamination, (2) layers with a cloud-aerosol discrimination (CAD) score falling outside the range of -100 to -20 , (3) aerosol layers with uncertainty flags of $99.9 \mathrm{~km}^{-1}$ and the layers beneath, (4) extinction QC flags indicating possible large errors, and (5) "clear air" under the lowest detected aerosol layer with base below $250 \mathrm{~m}$ to avoid low bias for undetected surface-attached aerosols. In addition, we exclude very high values of aerosol extinction $\left(>0.35 \mathrm{~km}^{-1}\right.$ ) below $2 \mathrm{~km}$ poleward of $60^{\circ}$ during cold months (September-May for the Arctic and MarchNovember for the Antarctic), as they are likely related to diamond dust misclassified as aerosols (Di Pierro et al., 2013).

The CALIOP nighttime retrievals over polar regions are limited during summer months (May-July in the Arctic, November-January in the Antarctic), with maximum latitudinal extents of $55^{\circ}$ latitude beyond which only daytime retrievals are available. Daytime retrievals have higher detection thresholds and can only detect aerosol layers with relatively high extinction (Figs. S1-S2). Therefore, at a given latitude fewer aerosol layers are detected in the daytime retrievals, and the average daytime extinction coefficients are lower than the nighttime ones over polar regions (Fig. S3). Most of our work is based on analysis of nighttime CALIOP retrievals during winter over polar regions. However, to reconstruct the full seasonal cycle of aerosol extinction over polar regions, we calculate nighttime equivalent aerosol extinction profiles by combining both daytime and nighttime CALIOP extinction coefficients, following the algorithm described in Di Pierro et al. (2013). This approach provides an empirical correction for the differences in detection sensitivity and aerosol extinction in the daytime CALIOP retrievals (more details are given in the Supplement).

\subsection{The GEOS-Chem chemical transport model}

We use the GEOS-Chem (v10-01) 3-D global chemical transport model (Bey et al., 2001) driven by meteorological fields from the Modern-Era Retrospective Analysis for Research and Applications (MERRA; Rienecker et al., 2011). The MERRA assimilated meteorological fields have a native horizontal resolution of $0.5^{\circ}$ latitude by $0.666^{\circ}$ longitude with 72 vertical levels, which we regrid to $2^{\circ} \times 2.5^{\circ}$ horizontal resolution and 47 vertical levels with merged levels above $80 \mathrm{hPa}$.
We conduct a 3-year (2007-2009) global simulation of tropospheric aerosol-oxidant chemistry. The model is initialized with a 1-year spin up. Global anthropogenic emissions are from the Emissions Database for Global Atmospheric Research (EDGAR v4.2; Olivier and Berdowski, 2001) for 1970-2008. For the years after 2008, anthropogenic emissions are scaled relative to year 2008, based on governmental statistics for different countries and regions (van Donkelaar et al., 2008). Over North America, the anthropogenic emissions are from the 2011 National Emissions Inventory (NEI11v6.1) produced by the US Environmental Protection Agency (EPA), with annual scaling factors from the EPA for other years. Over Asia, the anthropogenic emissions are from the MIX emission inventory ( $\mathrm{Li}$ et al., 2017). Over Europe, we use anthropogenic emissions from the Co-operative Programme for Monitoring and Evaluation of Long-range Transmission of Air Pollutants in Europe (EMEP). Monthly biomass burning emissions are from the Global Fire Emissions Database version 4 (GFEDv4; van der Werf et al., 2010). Black carbon (BC) and organic carbon (OC) emissions are based on the Bond et al. (2007) monthly emission inventory, including sources from fossil fuel and biofuel. Dust emissions are based on the dust entrainment and deposition scheme from Zender et al. (2003). Biogenic emissions of volatile organic compounds (VOCs) are from the Model of Emissions of Gases and Aerosols from Nature version 2.1 (MEGAN 2.1, Guenther et al., 2012). The $\mathrm{HO}_{x}-\mathrm{NO}_{x}-\mathrm{VOC}-\mathrm{O}_{3}-\mathrm{BrO}_{x}$ tropospheric chemistry chemical mechanism is described in Mao et al. (2010, 2013), with recent updates in biogenic VOC chemistry (Fisher et al., 2016; Travis et al., 2016). The gas-particle partitioning of $\mathrm{SO}_{4}^{2-}-\mathrm{NO}_{3}^{-}-\mathrm{NH}_{4}^{+}$aerosol is computed with the ISORROPIA II thermodynamic module (Fountoukis and Nenes, 2007) as implemented by Pye et al. (2009).

The open-ocean emissions of SSA are a function of wind speed and sea surface temperature (SST) as described in Jaeglé et al. (2011). In Huang and Jaeglé (2017), we inferred that wave-breaking SSA emissions are suppressed during summer at coastal polar sites with cold waters $\left(\mathrm{SST}<5^{\circ} \mathrm{C}\right)$. As in Huang and Jaeglé (2017), we reduce SSA emissions for these cold waters. We use two SSA size bins: the accumulation mode $\left(r_{\text {dry }}=0.01-0.5 \mu \mathrm{m}\right)$ and coarse mode $\left(r_{\text {dry }}=\right.$ 0.5-8 $\mu \mathrm{m})$.

Advection is based on the Lin and Rood (1996) advection algorithm, and boundary-layer mixing is computed using the non-local scheme in Lin and McElroy (2011). Dry deposition in GEOS-Chem follows a standard resistance-inseries scheme based on Wesely (1989), as described by Wang et al. (1998). The dry deposition of SSA in the model follows the Zhang et al. (2001) size-dependent scheme over land and is calculated based on the Slinn and Slinn (1980) deposition model over ocean and sea ice, as implemented by Jaeglé et al. (2011) in GEOS-Chem. The strong size dependence of SSA deposition is taken into account by integrating the dry deposition velocity over each of the two SSA size 
bins using a bimodal size distribution including growth as a function of local relative humidity $(\mathrm{RH})$. The hygroscopic growth of SSA follows the parameterization of Lewis and Schwartz (2006). The sedimentation of SSA is calculated throughout the atmospheric column based on the Stokes velocity scheme. The wet deposition of aerosols includes convective updraft, washout, and rainout from precipitation (Liu et al., 2001) as well as snow scavenging (Wang et al., 2011). The aerosol extinction coefficients at $550 \mathrm{~nm}$ calculated in GEOS-Chem are a function the mass concentrations, extinction efficiency, and mass density based on Mie theory, and they take into account the hygroscopic growth of aerosols as described in Martin et al. (2003), with an updated size distribution for SSA (Jaeglé et al., 2011).

The blowing snow SSA emissions in GEOS-Chem are based on the parameterization of Yang et al. (2008, 2010), as implemented by Huang and Jaeglé (2017). The SSA production from blowing snow is a function of $\mathrm{RH}$, temperature, age of snow, snow salinity, and wind speed. The size distribution of wind-lifted snow particles follows a twoparameter gamma distribution (Yang et al., 2008, and references therein). Once sublimated, snow particles are released as SSA particles. We assume that 5 SSA particles are produced per snowflake $(N=5)$, based on a comparison against observations of submicron SSA mass concentrations at Barrow, Alaska (Huang and Jaeglé, 2017). The size distribution of blowing snow SSA is determined from the size distribution of snow particles, $\mathrm{N}$, and salinity. The resulting emitted mass of blowing snow SSA is obtained by integrating this size distribution into the two SSA size bins. In our previous work, we had assumed a uniform salinity on Arctic (0.1 psu) and Antarctic sea ice ( $0.03 \mathrm{psu})$ based on mean observations of surface snow salinity (Mundy et al., 2005; Krnavek et al., 2012). Here we use these salinities for FYI, but now we take into account the lower surface snow salinity of older sea ice by assuming that MYI snow salinity is 10 times lower than on FYI (Krnavek et al., 2012): 0.01 psu on Arctic MYI snow and 0.003 psu on Antarctic MYI snow. We calculate a mean snow age of 3 days for the Arctic and 1.5 days for the Antarctic from MERRA meteorological fields.

Frost flower SSA emissions follow the emission scheme of Xu et al. (2013), which is based on the empirical wind dependence of Shaw et al. (2010) and the potential frost flower (PFF) coverage of Kaleschke et al. (2004). The PFF is a function of ambient air temperature, and frost flowers are formed on very new and young sea ice once the ambient air temperature is cold enough $\left(<\right.$ about $\left.-20^{\circ} \mathrm{C}\right)$. We set a threshold of $10 \mathrm{~cm}$ for the thickness of newly formed sea ice, beyond which we assume that frost flowers do not form due to inefficient brine transport through thicker sea ice. The size distribution of SSA from frost flowers follows a lognormal size distribution with a geometric mean diameter of $0.015 \mu \mathrm{m}$ and a geometric standard deviation of 1.9 (Xu et al., 2013). This size distribution is integrated into the two GEOS-Chem SSA size bins to obtain the emitted mass of SSA from frost flowers.

The sea-ice-concentration boundary conditions in MERRA are derived from the weekly product of Reynolds et al. (2002), which is based on Special Sensor Microwave Imager (SSMI) instruments on Defense Meteorological Satellite Program (DMSP) satellites. The weekly products have an original spatial resolution of $1^{\circ} \times 1^{\circ}$ and are linearly interpolated in time to each model time step. For each year, we use the preceding summertime minimum sea ice extent in MERRA (September in the Arctic and February in the Antarctic) to infer the location of MYI. The FYI extent is calculated by subtracting the MYI extent from the total sea ice extent (Fig. S4).

In this study, we neglect the role of leads as a source of SSA as we found in Huang and Jaeglé (2017) that, while this additional source could potentially be important on local scales near leads, overall the regional increase in SSA emissions is less than $10 \%$.

Our standard simulation (STD) includes tropospheric aerosol-oxidant chemistry and SSA emissions from the open ocean. The STD+Snow simulation is the STD simulation to which we add SSA emissions from blowing snow as in Huang and Jaeglé (2017), with surface snow salinities as described above $(0.1 \mathrm{psu}$ on FYI and 0.01 psu on MYI over the Arctic and 0.03 psu on FYI and 0.03 psu on MYI over the Antarctic). The STD+FF simulation is the STD simulation with SSA emissions from frost flowers. In Sect. 4, we develop an optimized blowing snow simulation (STD+Opt. Snow), with seasonally varying surface snow salinity on FYI.

The GEOS-Chem simulations are sampled at the time and location of the CALIOP overpasses and averaged over the same horizontal and vertical grid. For comparison to CALIOP observations, we apply the CALIOP nighttime detection threshold to the model, setting the modeled backscatter coefficients to $0 \mathrm{Mm}^{-1} \mathrm{sr}^{-1}$ for backscatter values lower than $0.2 \mathrm{Mm}^{-1} \mathrm{sr}^{-1}$.

\section{Model evaluation with CALIOP observations}

\subsection{Arctic}

The Arctic cold-season (November-April) CALIOP extinction coefficients in the lower troposphere $(0-2 \mathrm{~km}$ above sea level, $\mathrm{km}$ a.s.l.) display values of $10-30 \mathrm{Mm}^{-1}$ (Fig. 1a). The largest extinction coefficients occur over the open-ocean regions of the Greenland and Barents seas. In addition, significant aerosol extinction coefficients $\left(10-20 \mathrm{Mm}^{-1}\right)$ are seen over the sea-ice-covered Chukchi Sea, East Siberian Sea, Laptev Sea, Kara Sea, and Canadian Arctic Archipelago (Fig. 1a). While the STD GEOS-Chem simulation reproduces the pattern of extinction over the open ocean regions, it fails to capture the enhancements over sea ice, underestimating aerosol extinction coefficients by $\sim 10 \mathrm{Mm}^{-1}$ over the 


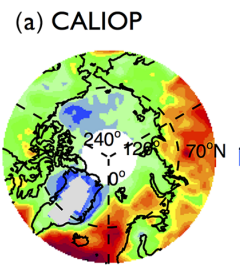

(b) STD

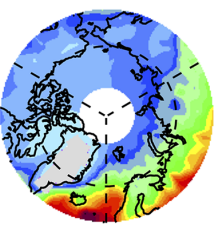

(c) STD+Snow

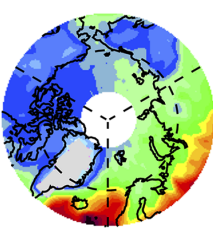

(d) STD+Opt. Snow

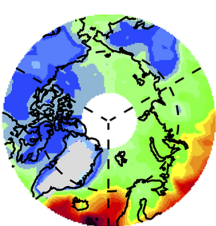

(e) STD+FF

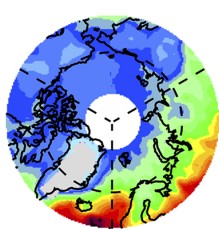

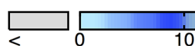

$\mathrm{Mm}^{-1}$

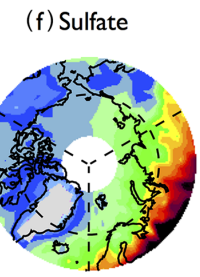

(g) Ocean SSA

(h) Blowing snow SSA (i) Opt. blowing snow SSA

SSA (j) Frost flower SSA
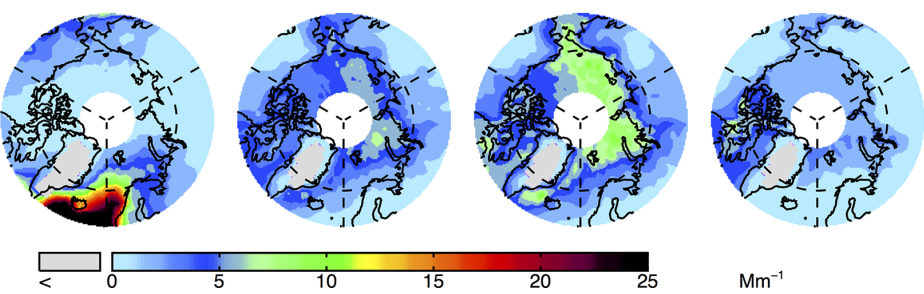

$\mathrm{Mm}^{-1}$

Figure 1. Spatial distribution of mean aerosol extinction coefficients (0-2 km) during the 2007-2009 Arctic cold season (November-April), (a) observed by CALIOP and calculated with the GEOS-Chem model in (b) a standard simulation (STD), (c) a simulation including blowing snow SSA emissions (STD+Snow), (d) an optimized blowing snow simulation (STD+Opt. Snow), and (e) a simulation including frost flower SSA emissions (STD+FF). The simulated extinction coefficients are sampled at the time and location of the CALIOP overpasses, and the CALIOP sensitivity threshold is applied. The bottom panels show the extinction coefficients of individual aerosol components in the GEOS-Chem simulations: (f) sulfate aerosol, (g) open ocean SSA, (h) blowing snow SSA, (i) Opt. blowing snow SSA, and (j) frost flower SSA. Note the different color-bar scales for the top and bottom rows.
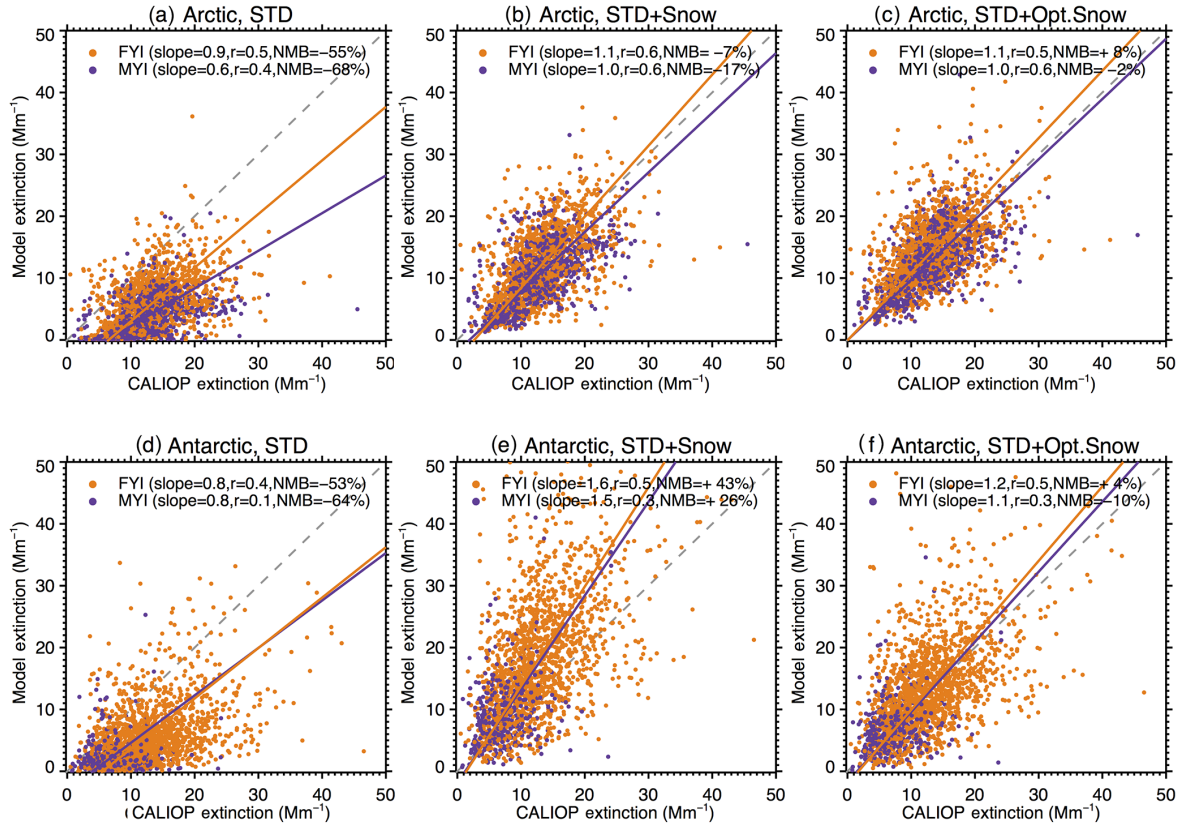

Figure 2. Scatter plot of CALIOP and GEOS-Chem aerosol extinction coefficients over FYI (orange circles) and MYI (purple circles) for the Arctic cold season (November-April, a-c) and Antarctic cold season (May-October, d-f). Each symbol represents the monthly aerosol extinction coefficients for individual grid boxes $\left(2^{\circ} \times 5^{\circ}, 0-2 \mathrm{~km}\right)$ over sea ice. The dashed gray line is the $1: 1$ line. The purple and orange lines are the linear fit for the points over MYI and FYI, respectively. The slope of the regression line, correlation coefficient $(r)$, and normalized mean bias, $\mathrm{NMB}=100 \times(\overline{\mathrm{Model}} / \overline{\mathrm{Obs}}-1)$, are shown for each panel. 
(a) FYI

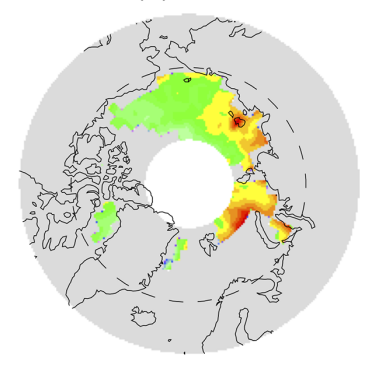

(b) MYI

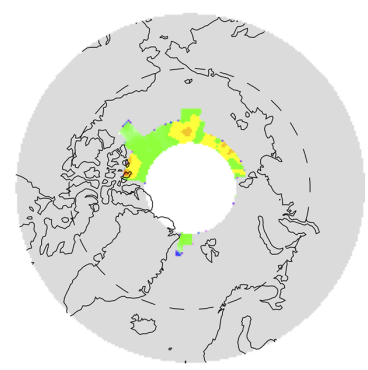

(c) FF

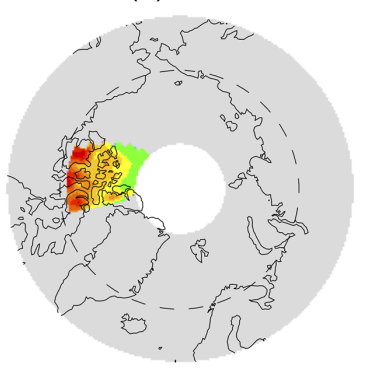

$\mathrm{Mm}^{-1}$ (d) FYI

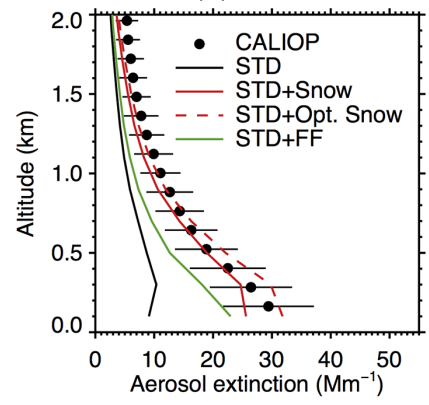

(g) $\mathrm{FYI}$

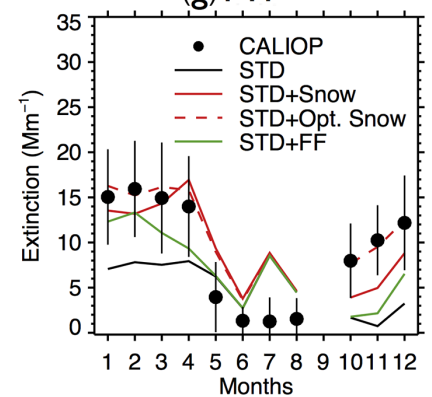

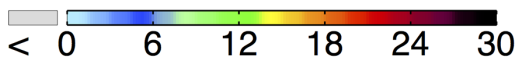

(e) MYI (f) FF

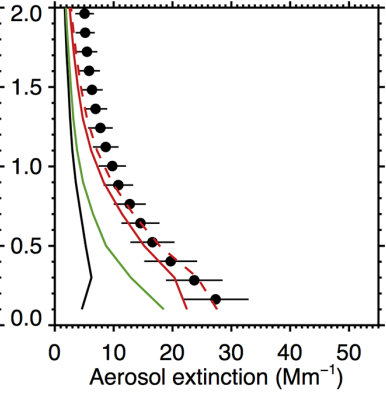

(h) MYI

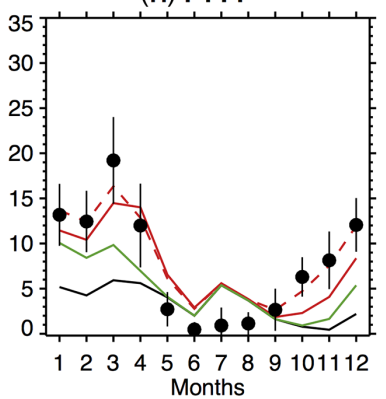

(i) FF

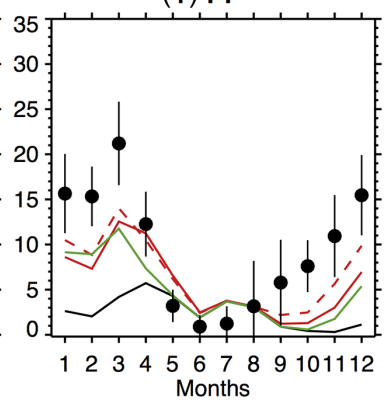

Figure 3. (a-c) 2007-2009 CALIOP mean aerosol extinction coefficients (0-2 km) in the Arctic cold season (November-April) over (a) firstyear sea ice (FYI), (b) multi-year sea ice (MYI), and (c) the Canadian Arctic Archipelago (CAA). (d-f) vertical profiles of Arctic coldseason mean aerosol extinction coefficients over (d) FYI, (e) MYI, and (f) CAA for CALIOP (black dots with horizontal lines indicating standard deviations) and GEOS-Chem model simulations (STD: black lines, STD+Snow: red solid lines, STD+Opt. Snow: red dashed lines, STD+FF: green lines). (g-i) seasonal cycle of 0-2 km monthly aerosol extinction coefficients averaged over (g) FYI, (h) MYI, and (f) CAA. CALIOP observations are shown as black circles, and vertical lines indicate the interannual standard deviation. The four GEOS-Chem model simulations are also shown (STD: black lines, STD+Snow: red solid lines, STD+Opt. Snow: red dashed lines, STD+FF: green lines).

central Arctic (Fig. 1b). The normalized mean bias (NMB $\mathrm{NMB}=100 \times(\overline{\mathrm{Model}} / \overline{\mathrm{Obs}}-1)$, with $\overline{\text { Model }}$ and $\overline{\mathrm{Obs}}$ representing mean observed and modeled values) is $-55 \%$ over FYI and $-68 \%$ over MYI (Fig. 2a). GEOS-Chem also underestimates CALIOP aerosol extinction over northern Russia, which could be due to missing sources of aerosols and their precursors from gas flaring in the region (Li et al., 2016; Klimont et al., 2017; Xu et al., 2017).

In the STD simulation, aerosol extinction coefficients during the cold season are dominated by SSA over the high latitude open ocean and by the long-range transport of sulfate aerosols over sea ice (Fig. 1f and g). Adding blowing snow emissions of SSA increases the simulated aerosol extinction by $\sim 10 \mathrm{Mm}^{-1}$ over the central Arctic, bringing the STD+Snow simulation in better agreement with CALIOP observations (Fig. 1c and h), with a model bias of $-7 \%$ on FYI and $-17 \%$ on MYI (Fig. 2b). The inclusion of frost flower emissions of SSA in the STD+FF simulation has the largest influence over Canadian Arctic Archipelago, where cold temperatures and open leads co-exist (Fig. 1j), but the overall magnitude of the increase cannot explain the CALIOP aerosol extinction coefficients. Monthly maps of the comparison between CALIOP and GEOS-Chem simulations are included in the Supplement (Fig. S5). 
(a) CALIOP

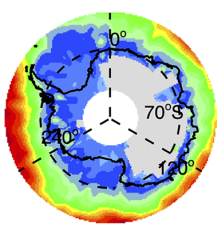

(b) STD

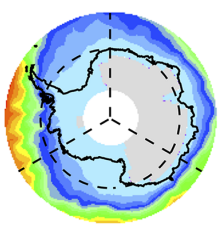

(c) STD+Snow

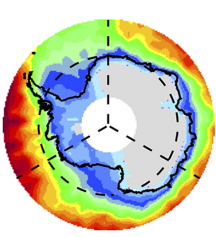

(d) STD+Opt. Snow

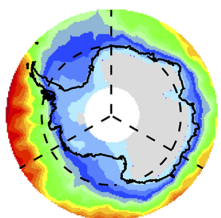

(e) STD+FF

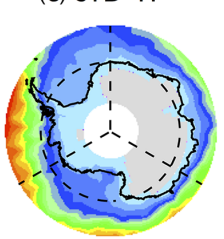

$\mathrm{Mm}^{-1}$

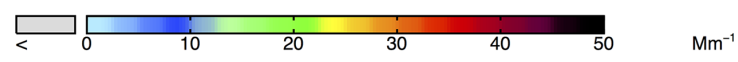

(f) Ocean SSA (g) Blowing snow SSA (h) Opt. blowing snow SSA (i) Frost flower SSA

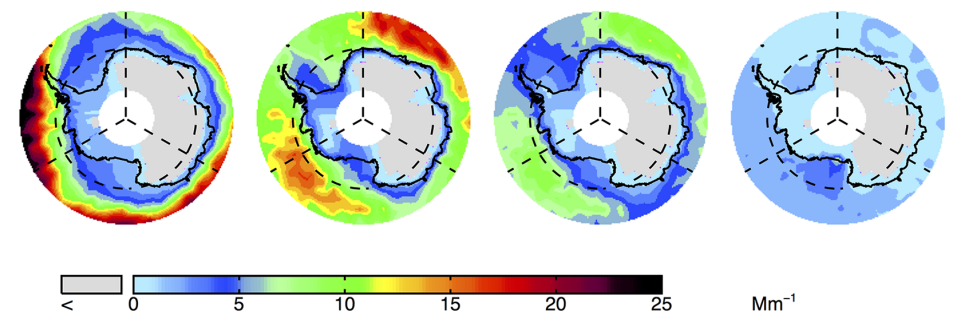

Figure 4. Spatial distributions of mean aerosol extinction coefficients (0-2 km) during the 2007-2009 Antarctic cold season (May-October), (a) observed by CALIOP and calculated with the GEOS-Chem (b: STD, c: STD+Snow, d: STD+Opt. Snow, e: STD+FF). The bottom panels show the extinction of individual aerosol components in the GEOS-Chem simulations: (f) open ocean SSA, (g) blowing snow SSA, (h) Opt. blowing snow SSA, and (i) frost flower SSA. Note the different color-bar scales for the top and bottom rows.

Figure 3 compares the vertical and seasonal distribution of aerosol extinction coefficients in the lower troposphere (0-2 km altitude) over FYI, MYI, and the Canadian Arctic Archipelago, where frost flowers are expected to have their largest influence (Huang and Jaeglé, 2017). Over all three regions, the STD simulation underestimates cold season CALIOP extinction by factors of 3-6 (Fig. 3d and f). The STD+FF simulation reduces the negative model bias, but the modeled extinction remains $20 \%-40 \%$ too low (Fig. 3d-f). Furthermore, the STD+FF simulation does not capture the rapid increase in CALIOP extinction in October-December (Fig. 3g-i). We find that applying a single scaling factor to the frost flower emissions cannot address the seasonally varying model discrepancy. In comparison, the STD+Snow simulation displays the best agreement with the CALIOP observations, reproducing the observed vertical profile and seasonal cycle. The STD+Snow simulation, however, underestimates the CALIOP aerosol extinction in October-December by $30 \%-50 \%$ (Fig. $3 \mathrm{~g}$ and $\mathrm{f}$ ) and underestimates the surface CALIOP cold-season aerosol extinction by up to $5 \mathrm{Mm}^{-1}$ (Fig. 3d and e). In addition, it predicts a maximum in aerosol extinction during April, while CALIOP observations display their largest extinction coefficients in January-March for FYI and in March over MYI.

\subsection{Antarctic}

During the austral cold season (May-October), CALIOP aerosol extinction coefficients decrease with increasing latitudes, ranging from 20 to $30 \mathrm{Mm}^{-1}$ at $60^{\circ} \mathrm{S}$ to $5-10 \mathrm{Mm}^{-1}$ near coastal Antarctica (Fig. 4a). Over Antarctic FYI
(Fig. 5a), CALIOP aerosol extinction displays values of 10$14 \mathrm{Mm}^{-1}$ in July-October in the lower troposphere (Fig. $5 \mathrm{~g}$ ), with aerosol extinction attaining $30 \mathrm{Mm}^{-1}$ near the surface (Fig. 5d). Over MYI sea ice offshore of the Ronne Ice Shelf, the CALIOP extinction is somewhat smaller, reaching $20 \mathrm{Mm}^{-1}$ near the surface (Fig. 5e).

Poleward of $70^{\circ} \mathrm{S}$, open ocean SSA dominate aerosol extinction coefficients in the STD simulation (Fig. 4f), accounting for $80 \%$ of the extinction, with the remaining $20 \%$ due to the combined contributions from sulfate, black carbon, and organic aerosols. The STD simulation underestimates CALIOP observations by $5-10 \mathrm{Mm}^{-1}$ (Fig. $5 \mathrm{~g}-\mathrm{i}$ ), with a $-53 \%$ bias over FYI and a $-64 \%$ bias over MYI (Fig. 2 d). The inclusion of frost flowers in the STD+FF simulation leads to a $\sim 2 \mathrm{Mm}^{-1}$ increase in extinction coefficients near the Ross and Ronne ice shelves, where cold temperatures and open leads persist (Fig. 4i). This increase is insufficient in explaining CALIOP observations (Figs. 4e and 5).

The STD+Snow simulation increases aerosol extinction coefficients by $10-20 \mathrm{Mm}^{-1}$ in the Indian Ocean $\left(0-100^{\circ}\right)$ and Pacific Ocean $\left(180-270^{\circ}\right.$ ) sectors (Fig. 4g), where strong winds persist. We find that the inclusion of blowing snow SSA emissions results in a $43 \%$ overestimate of CALIOP extinction over FYI sea ice (Fig. 2e) and too strong of a seasonal increase in extinction between May and October (Fig. 5g). Over the smaller MYI region, the positive bias of the STD+Snow simulation is $+26 \%$ (Figs. 2e, 5e and h). Monthly maps comparing CALIOP and GEOS-Chem are included in the Supplement (Fig. S6). 
(a) FYI

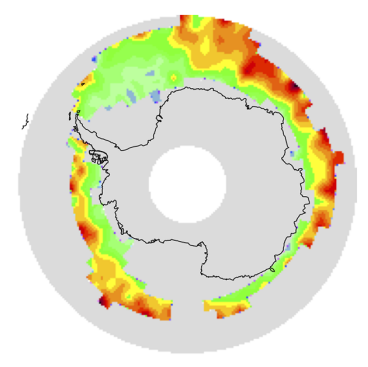

(b) MYI

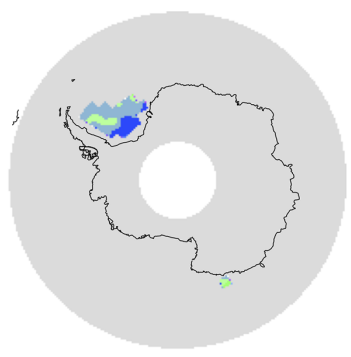

(c) FF

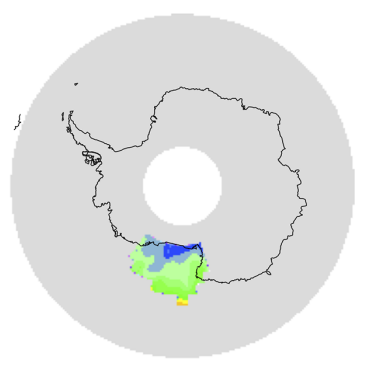

$\mathrm{Mm}^{-1}$ (d) FYI

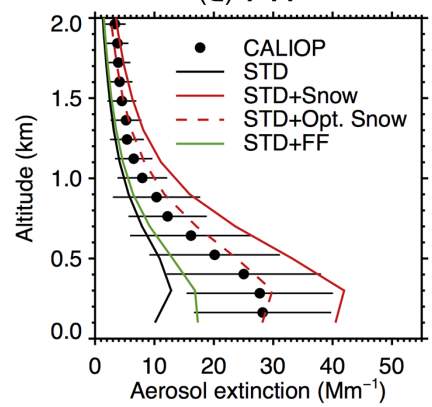

(g) FYI

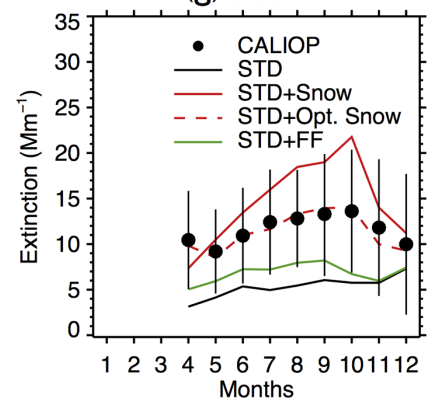

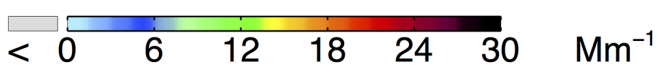

(e) MYI

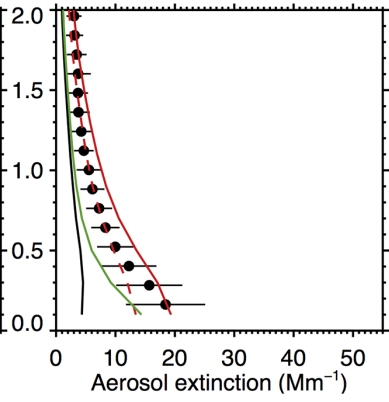

(h) MYI

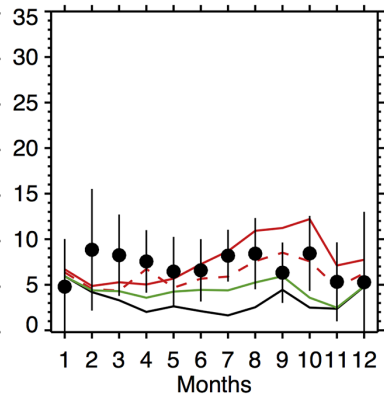

(f) $\mathrm{FF}$

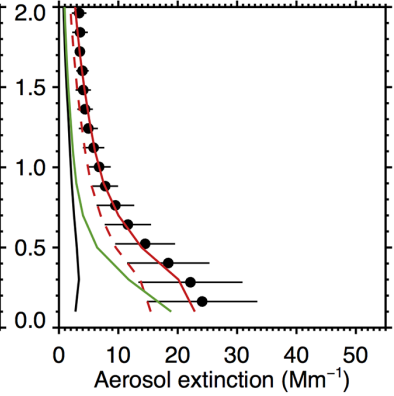

(i) FF

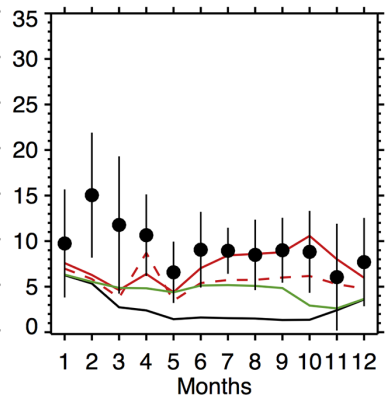

Figure 5. Same as Fig. 3, but for Antarctic aerosol extinction coefficients during austral winter (May-October) over (a) FYI (excluding offshore Ross Ice Shelf), (b) MYI, and (c) offshore Ross Ice Shelf. As shown in (g), the monthly average aerosol extinction coefficients are not available over FYI during Antarctic summer (January-March) due to the limited FYI extent.

\section{Blowing snow simulation with optimized snow salinity}

While the inclusion of blowing snow leads to improved agreement with CALIOP, we hypothesize that the remaining discrepancies in the magnitude and seasonal cycle of aerosol extinction coefficients are due to our simplified assumption of a temporally uniform surface snow salinity over FYI.

As discussed in Sect. 1, the surface snow salinity is highest over thin FYI with little snow cover early in the cold season, declining in the ensuing months as a result of thickening sea ice and increasing snowpack depth (Barber et al., 1995; Krnavek et al., 2012; Weeks and Lee, 1958; Weeks and Ackley, 1986; Nakawo and Sinha, 1981). As no systematic observations of surface snow salinity are available over sea ice, our approach is to find the monthly salinity of snow on FYI required to minimize the discrepancy between CALIOP extinction and the GEOS-Chem simulation. The salinity of surface snow on MYI is the same as in the STD+Snow simulation.

By using a linear regression between the GEOS-Chem simulation and CALIOP monthly extinction over Arctic sea ice, we derive a surface snow salinity on FYI of 0.9 psu in September, decreasing to $0.09 \mathrm{psu}$ in April (with values of $0.36,0.26,0.19,0.16,0.16$, and 0.14 between October and March). The inferred snow salinities decrease with time and are generally consistent with observations near Alaska reported by Krnavek et al. (2012): 0.8 psu for snow over recently frozen thin FYI and 0.1 psu over thick FYI. For Antarctic FYI, we infer snow salinities of 0.05 psu in April, 0.02 in May-June, and 0.018 in July-September. For the rest 
of the year the salinity is 0.015 psu. These decreasing trends in salinity between fall and spring are consistent with expectations based on the seasonal evolution of FYI thickness, sea ice surface salinity, and deepening snow cover (Worby et al., 1998; Warren et al., 1999; Massom et al., 2001; Kwok and Cunningham, 2015).

We use our empirically derived monthly snow salinities to conduct an optimized blowing snow simulation (STD+Opt. Snow). Over Arctic FYI, the model bias changes from $-7 \%$ (STD+Snow) to $+8 \%$ (STD+Opt. Snow), and for MYI, the model bias of $-17 \%$ changes to $-2 \%$ (Fig. $2 b$ and c). Over Antarctic FYI, the model overestimate decreases from $+43 \%$ (STD+Snow) to +4\% (STD+Opt. Snow). Similarly, the model bias over MYI decreases to $-10 \%$ (Fig. 2e and f). The STD+Opt. Snow simulation displays cold-season extinction profiles that are within 5-10\% of CALIOP observations over sea ice (Figs. 3d-e and 5d-e). The seasonal cycles are in better agreement with observations, especially in the Arctic for October-December, when the inferred FYI salinities (0.36-0.19 psu compared to 0.1 psu in the STD+Snow simulation) lead to a near doubling of aerosol extinction (Fig. 3g-h). Over Antarctica, the amplitude of the seasonal cycle of aerosol extinction over FYI is reduced, in better agreement with CALIOP observations (Fig. $5 \mathrm{~g}-\mathrm{h}$ ).

We also examined whether a single fixed value of salinity over FYI can lead to similar improvements in the agreement with CALIOP. The resulting fixed salinities are $0.11 \mathrm{psu}$ over Arctic FYI and 0.018 psu over Antarctic FYI, leading to good overall agreement with CALIOP over the Antarctic (NMB of $+5 \%$ on FYI and $-9 \%$ on MYI) but with no significant improvement seen in the Arctic (NMB of $-7 \%$ on FYI and $-18 \%$ on MYI). We found that over the Arctic, a simulation using a single salinity of $0.11 \mathrm{psu}$ (STD+Const. Snow, Fig. S8g-h) yields results similar to the STD+Snow simulation and cannot explain the high extinction values during fall and early winter. Over Antarctic sea ice, the performance of a simulation with 0.018 psu over FYI shows results similar to the STD+Opt. Snow simulation. Thus there is a stronger case for using a seasonally varying snow salinity over Arctic sea ice than over Antarctic sea ice. We speculate that this might be linked to relatively smaller seasonal variation in sea ice thickness and snow depth for Antarctic sea ice compared to the Arctic. In their snow climatology, Warren et al. (1999) report that the mean snow depth at an Arctic sea ice site increased from $8.7 \mathrm{~cm}$ in October to $28.9 \mathrm{~cm}$ in March. Satellite-based observations of Arctic FYI thickness show an increase from $0.95 \mathrm{~m}$ in October to $2.15 \mathrm{~m}$ in May (Kwok and Cunningham, 2015). In contrast, over Antarctic sea ice, the mean sea ice thickness and snow depth remained fairly constant during fall-winter (April: $0.48 \mathrm{~m}$ for ice thickness and $0.11 \mathrm{~m}$ for snow depth, August: $0.52 \mathrm{~m}$ for ice thickness and $0.11 \mathrm{~m}$ for snow depth) as described in Worby et al. (1998).

Both STD+Snow and STD+Opt. Snow simulations underestimate CALIOP aerosol extinction over the Canadian Arctic Archipelago (Fig. 3f). Combining the STD+Opt.
Snow and frost flower emissions could help improve the agreement in that region, but it would also lead to substantial overestimates over FYI and MYI for the rest of the Arctic. One possibility is that snow-covered frost flowers in the Canadian Archipelago increase the local surface snow salinity (Domine et al., 2004). The recent study of Hara et al. (2017) in northwestern Greenland proposed that snowfall buries frost flowers and the associated slush layer on new FYI. The resulting brine migrates vertically, enriching the surface snow layer, which can be mobilized under strong winds. We estimate that increasing the salinity of snow over the Canadian Archipelago to a value of 3 psu would help reconcile the optimized blowing snow simulation with CALIOP observations. Direct measurements of snow salinity in this region would help confirm this estimate. Similarly, we find that increasing the snow salinity near the Ross Ice Shelf region, where frost flowers are expected to occur, would improve the agreement with CALIOP observations.

Figure 6 evaluates the performance of the STD+Opt. Snow simulation against independent observations of SSA mass concentrations in Barrow, Alaska $\left(71.3^{\circ} \mathrm{N}, 156.6^{\circ} \mathrm{W}\right)$; Alert, Nunavut, Canada $\left(82.5^{\circ} \mathrm{N}, 62.5^{\circ} \mathrm{W}\right)$; Zeppelin, Svalbard, Norway $\left(78.9^{\circ} \mathrm{N}, 11.9^{\circ} \mathrm{E}\right)$; Neumayer, Antarctica $\left(70.7^{\circ} \mathrm{S}, 8.3^{\circ} \mathrm{W}\right)$; and Dumont d'Urville, Antarctica $\left(66.7^{\circ} \mathrm{S}, 140^{\circ} \mathrm{E}\right)$. Descriptions of the in situ observations are provided in Huang and Jaeglé (2017). At Barrow, the optimized simulation improves the agreement with observed SSA mass concentrations in November-May. In particular, the enhanced salinity in October-November brings the model closer to the observations. At Zeppelin and Dumont d'Urville, the model bias in the STD+Opt. Snow simulation is reduced relative to the STD+Snow simulation. However, the model bias worsens at Neumayer (STD+Snow: $-25 \%$, STD+Opt. Snow: $-48 \%$ ), and the model bias remains large at Alert (STD+Snow: $-50 \%$, STD+Opt. Snow: $-32 \%)$. As Neumayer and Alert are close to the frost-flower-producing regions, compared to other polar sites, this underestimation may be related to an underestimation in the snow salinity in those regions.

It is also possible that the discrepancies between observed and modeled aerosol extinction coefficients are due to other factors in the blowing snow parameterization as implemented in GEOS-Chem. For example, our simulation does not include the negative feedback of water vapor sublimation (Mann et al., 2000); as blowing snow particles sublime in unsaturated air, they cause an increase in water vapor and thus the cooling of the surrounding air. Both effects lead to an increase in RH near saturation, reducing the sublimation rate. Another underlying assumption is that 5 SSA are produced for each snowflake that sublimes $(N=5)$. We conducted a sensitivity simulation assuming one SSA per snowflake, shown as STD+Snow $(N=1)$ in the Supplement (Figs. S7 and S8). This change does not affect the total emission of blowing snow SSA, but it decreases the fraction of SSA in the accumulation mode (see Huang and Jaeglé, 2017). As the ex- 

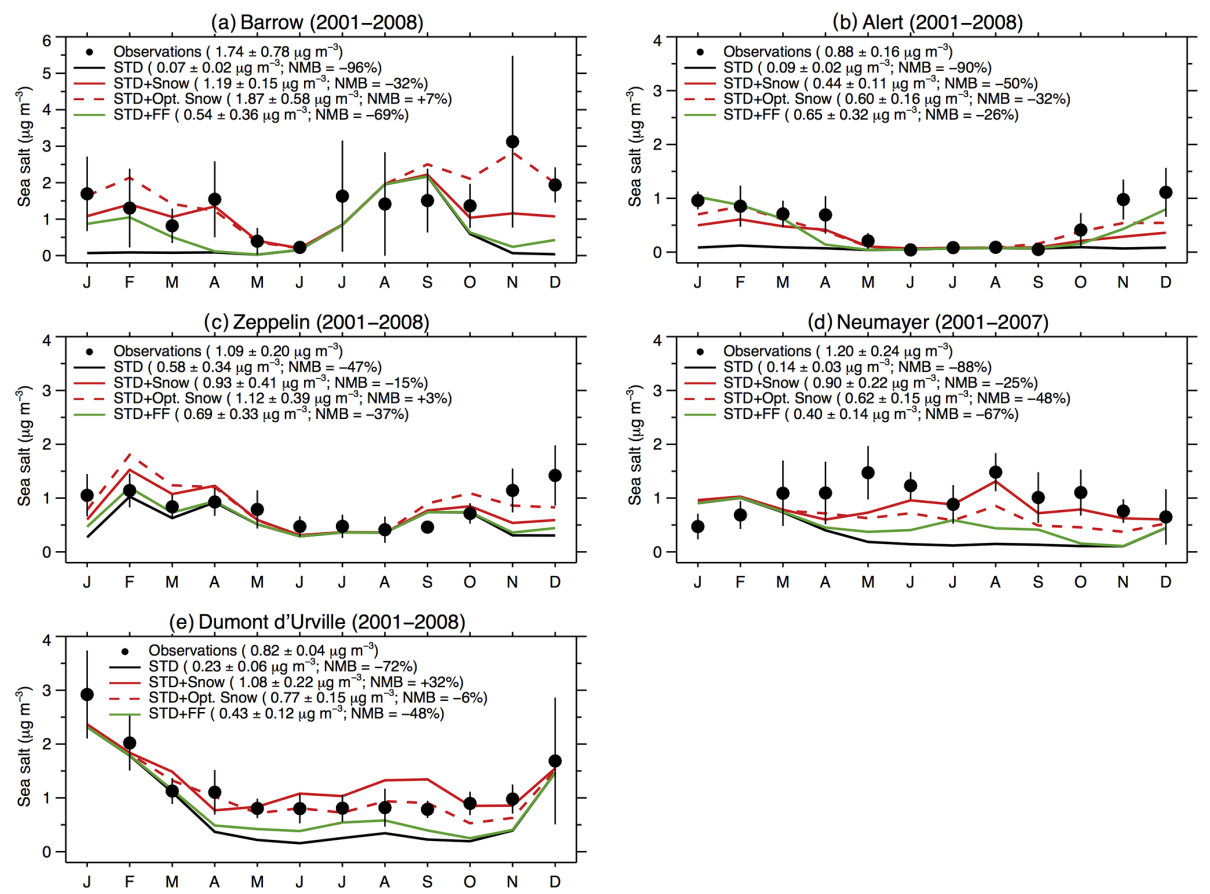

Figure 6. Monthly mean SSA mass concentrations at Arctic sites (a: Barrow, b: Alert, c: Zeppelin) and Antarctic sites (d: Dumont d'Urville, e: Neumayer). All observations and model results are for 2001-2008, except at Neumayer (2001-2007). The observed mean concentrations are indicated with filled black circles, and the lines are for the GEOS-Chem simulations (STD: black line, STD+Snow: red line, STD+Opt. Snow: red dashed line; STD+FF: green line). The black vertical lines are the standard deviations of monthly means for the observation years. For each individual panel, we list the cold season (Arctic: November-April; Antarctic: May-October) mean concentrations and standard deviations as well as the NMB.

tinction efficiency of accumulation mode SSA is larger than that of coarse mode SSA, the assumption of $N=1$ leads to a $30 \%-50 \%$ decrease in modeled extinction relative to the $\mathrm{STD}+\operatorname{Snow}(N=5)$ simulation. Overall, this results in improved agreement with CALIOP observations over Antarctic sea ice, but the CALIOP aerosol extinction is underestimated over the Arctic. Increasing the surface snow salinity over Arctic FYI can address the model discrepancy in aerosol extinction coefficients, but it will lead to a factor of 1.5-2 overestimate in SSA mass concentrations.

\section{Case study of a blowing snow event over the Arctic}

Figure 7 shows a case study of a blowing snow SSA event, which occurred on 6 November 2008 over the Arctic. The STD+Snow and STD+Opt. Snow simulations display enhanced extinction coefficients $\left(40-80 \mathrm{Mm}^{-1}\right)$ over the Barents Sea along the $60^{\circ} \mathrm{E}$ longitude line extending from the North Pole to $70^{\circ} \mathrm{N}$ (Fig. $7 \mathrm{~b}$ and c). This feature is due to blowing snow SSA, and it is not seen in the STD simulation (Fig. 7a) or the STD+FF simulation (not shown).

The CALIPSO 00:58-01:12 UTC overpass on 6 November 2008 transected this feature, with CALIOP aerosol extinction coefficients of $50-150 \mathrm{Mm}^{-1}$ between points A $\left(78^{\circ} \mathrm{N}, 52.5^{\circ} \mathrm{E}\right)$ and $\mathrm{B}\left(82^{\circ} \mathrm{N}, 110^{\circ} \mathrm{E}\right)$, labeled in Fig. $7 \mathrm{a}-$ c. The cross section along the CALIOP overpass shows that the large aerosol extinction coefficients are confined between the surface and $1-2 \mathrm{~km}$ altitude (Fig. 7e). This overpass region is mostly covered by FYI (Fig. 7d). We sampled GEOSChem along the same cross section, finding a very good correspondence in the spatial extent of the feature observed by CALIOP and simulated by the STD+Snow and STD+Opt. Snow simulations (Fig. 7g-i). The optimized blowing snow model predicts higher aerosol extinction due to larger surface snow salinity on FYI in November and is in better agreement with the $0-2 \mathrm{~km}$ CALIOP mean aerosol extinction coefficients (Fig. 7i).

We use the FLEXPART particle dispersion model (Stohl et al., 1998, 2005; Seibert and Frank, 2004) with meteorological data from ERA-Interim with a horizontal resolution of $0.5^{\circ}$ to track the origin of this feature. We release 100000 particles between points A and B at $0.01-2 \mathrm{~km}$ and track them back in time over 2 days. The air along the A-B transect in Fig. 7 originates from the $120-140^{\circ} \mathrm{E}$ sector at $60-90^{\circ} \mathrm{N}$ near the surface $(0-100 \mathrm{~m})$, on 4 November 2008 (Fig. 8a). This region is covered by both MYI and FYI (Fig. 7d). The STD+Snow model predicts enhanced blowing snow emissions in this region on 4 November 2008 (Fig. 8b). The CD transect in Fig. $8 \mathrm{~b}$ shows the CALIOP overpass at 01:11-01:24 UTC, 4 November 2008. This CALIOP transect 

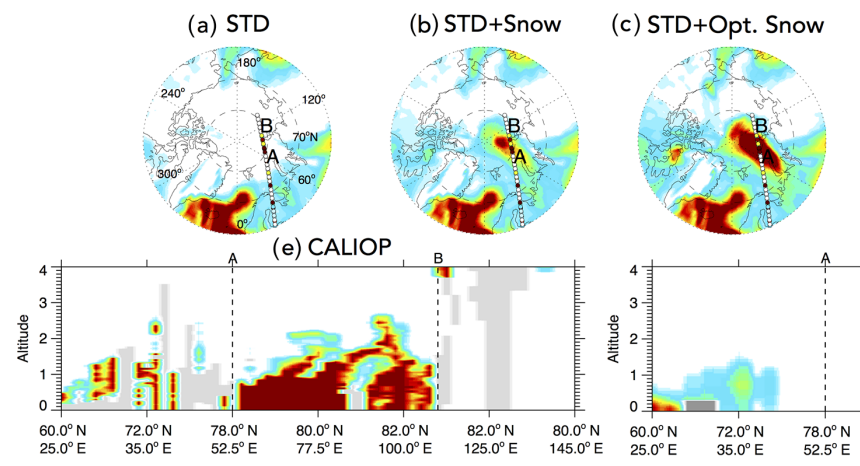

(d) Sea ice coverage
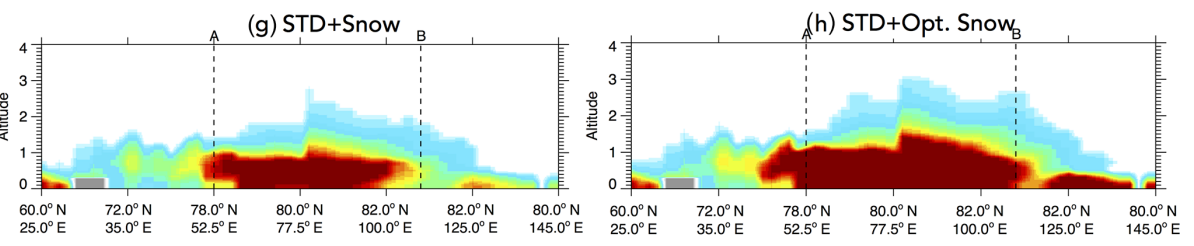

$$
<\begin{array}{lllllll}
\hline & 10 & 20 & 30 & 40 & 50 & \mathrm{Mm}^{-1}
\end{array}
$$

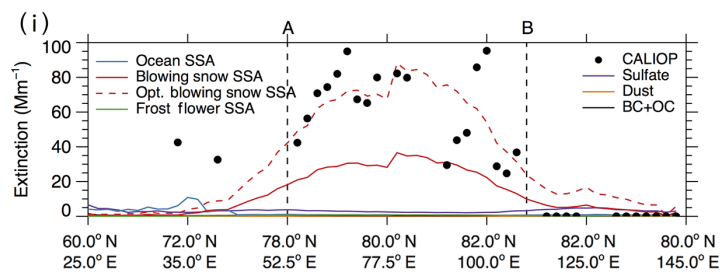

Figure 7. 6 November 2008 case study of a blowing snow SSA feature over the Arctic. Top panels: spatial distribution of mean aerosol extinction below $2 \mathrm{~km}$ altitude for the (a) STD, (b) STD+Snow, and (c) STD+Opt. Snow GEOS-Chem simulations. The CALIOP nighttime overpass at 00:58-01:12 UTC is displayed in the top panels, with filled circles color-coded according to observed mean extinction coefficients below $2 \mathrm{~km}$. The overpass intercepts the SSA blowing snow feature between points A and B. Panel (d) shows the MERRA sea ice coverage on 6 November 2008, with light gray shading indicating FYI and black shading for MYI. Panels (e-h) show the observed and simulated vertical cross sections of aerosol extinction coefficients along the CALIOP overpass. The light gray shading in (e) indicates that no valid data are available for CALIOP. The dark gray shading in (f-h) shows the local topography in the model. Panel (i) shows the 0-2 km CALIOP mean aerosol extinction and the contributions of different aerosol types in the GEOS-Chem simulations: sulfate aerosol, dust, black carbon and organic carbon $(\mathrm{BC}+\mathrm{OC})$, open ocean SSA, blowing snow SSA, optimized blowing snow SSA, and frost flower SSA.

displays elevated $532 \mathrm{~nm}$ attenuated perpendicular backscatter and depolarization ratios below $200 \mathrm{~m}$ (Fig. 8c and d), which are co-located with strong surface winds $\left(>5 \mathrm{~m} \mathrm{~s}^{-1}\right)$. The pattern of elevated backscatter, surface winds and depolarization ratios satisfies the requirements of the CALIOP blowing snow detection algorithm described in Palm et al. $(2011,2017)$, who defined blowing snow events as layers with high color ratios $(>1)$, high depolarization ratios $(>0.25)$, strong surface winds $\left(>4 \mathrm{~m} \mathrm{~s}^{-1}\right)$, and enhanced backscatter signals below $300 \mathrm{~m}$ (ranging between $2.5 \times 10^{-2}$ and $0.2 \mathrm{~km}^{-1} \mathrm{sr}^{-1}$ ). The FLEXPART-predicted source region and CALIOP blowing snow feature are co-located with enhanced blowing snow emissions in the GEOS-Chem simulation (Fig. 8b). This case study thus shows that CALIOP can detect not only the blowing snow event (Palm et al., 2011) but also the resulting SSA produced after sublimation.

\section{Discussion and conclusions}

In this work, we used the GEOS-Chem chemical transport model to assess the ability of the CALIOP lidar onboard the CALIPSO satellite to provide constraints on sea ice sources of SSA. We find that mean CALIOP aerosol extinction coefficients below $2 \mathrm{~km}$ altitude reach $10-15 \mathrm{Mm}^{-1}$ over seaice-covered regions during the 6 month polar cold season. The enhanced extinction is located below $2 \mathrm{~km}$, with the largest values $\left(20-35 \mathrm{Mm}^{-1}\right)$ occurring near the surface. We find that a standard GEOS-Chem simulation without sea ice sources of SSA underestimates CALIOP extinction by $50 \%-70 \%$ over Arctic and Antarctic sea ice. A simulation with frost flower SSA emissions is unable to explain the spatial and temporal distribution of CALIOP aerosol extinction. Adding a blowing snow SSA source results in improved agreement over the Arctic (NMB $=-7 \%$ for FYI and $\mathrm{NMB}=+17 \%$ over MYI) but yields a $43 \%$ overestimation of CALIOP extinction coefficients over Antarctic sea ice. 
(a) FLEXPART backward runs (04-11-2008)

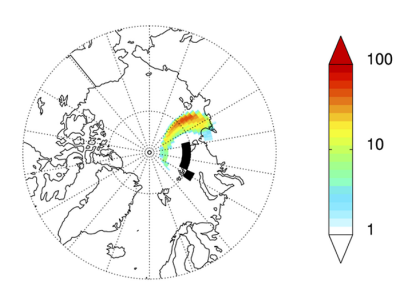

(b) Blowing snow emission (04-11-2008)

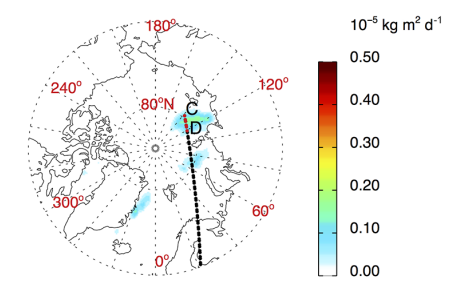

(c) CALIOP $532 \mathrm{~nm}$ perpendicular attenuated backscatter $\left(\mathrm{km}^{-1} \mathrm{sr}^{-1}\right)$ on 04-11-2008

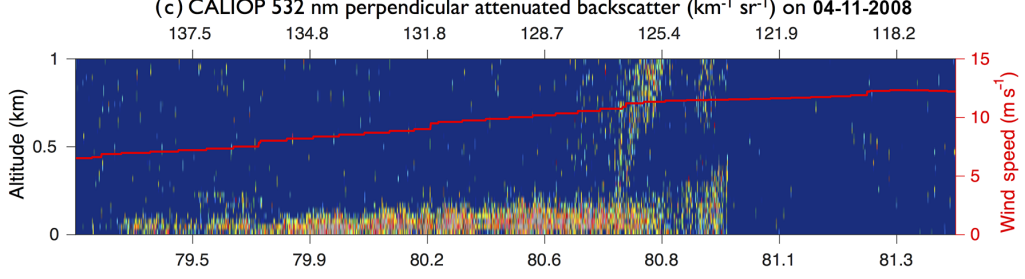

(d) CALIOP attenuated depolarization ratio on 04-11-2008
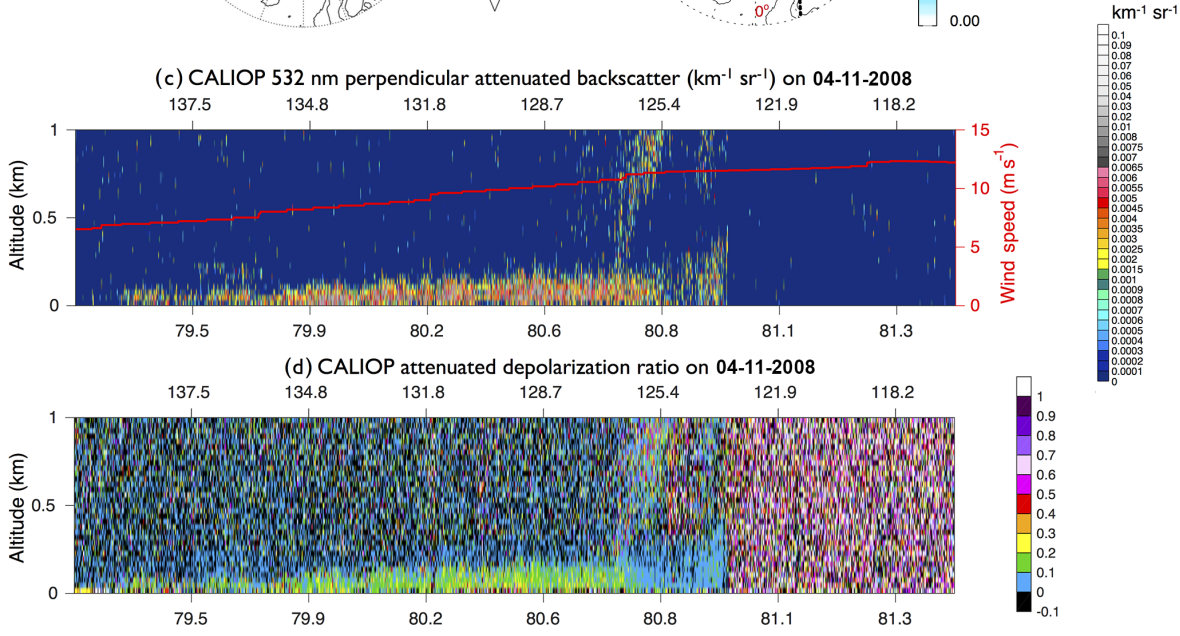

Figure 8. (a) The 4 November 2008 FLEXPART footprint below $100 \mathrm{~m}$ (in seconds) for particles initialized at $0-2 \mathrm{~km}$ over the black squares on 6 November 2008, near the blowing snow feature observed by CALIOP (Fig. 7). (b) 4 November 2008 blowing snow SSA emissions from the STD+Snow simulation, and the CALIOP overpass at 01:11-01:24 UTC on that day. (c) and (d) display CALIOP cross-sections between points $\mathrm{C}$ and $\mathrm{D}$ for (c) the $532 \mathrm{~nm}$ perpendicular attenuated backscatter $\left(\mathrm{km}^{-1} \mathrm{sr}^{-1}\right)$ and (d) attenuated depolarization ratio. The surface wind speed $\left(\mathrm{m} \mathrm{s}^{-1}\right)$ is shown with a red line in panel (c).

Additionally, the simulation including blowing snow SSA tends to underestimate CALIOP observations during fall to early winter (October-December over the Arctic and AprilJune over the Antarctic).

We hypothesize that our assumption of constant surface snow salinity on FYI ( 0.1 psu over the Arctic and 0.03 psu over the Antarctic) in the blowing snow simulation could explain the remaining discrepancies between observed and modeled extinction. Given the paucity of snow salinity observations, we infer the monthly surface snow salinity on FYI required to minimize the discrepancy between CALIOP and the GEOS-Chem simulation. The resulting snow salinities decrease progressively between the beginning and end of the cold season (from 0.9 to 0.09 psu for Arctic FYI; 0.05 to 0.018 psu over Antarctic FYI). This decrease is consistent with the seasonally increasing sea ice thickness and accumulating snow depth. The optimized blowing snow model using the monthly varying snow salinities shows improved agreement with CALIOP observations and in situ observations of SSA mass concentrations at five surface sites. However, the optimized blowing snow model tends to underestimate the aerosol extinction over the Canadian Arctic Archipelago and off the Ross Ice Shelf. Both regions are predicted to favor frost flower growth, which could locally increase the salinity of snow when frost flowers are buried under snow. We find that increasing the Canadian Arctic Archipelago FYI snow salinity to 3 psu would help reconcile our simulation with CALIOP and in situ observations. Our work, however, cannot rule out other alternative factors contributing to the discrepancy between modeled and observed aerosol extinction, such as the impact of the negative feedback of water vapor sublimation and our assumption about the number of particles produced per snowflake. Systematic observations of surface snow salinity over multiple sea ice locations and times would help further constrain snow salinities in the Arctic and Antarctic. Furthermore, more extensive observations of sea salt aerosol size distributions during blowing snow events could help further refine and constrain these assumptions.

We conduct a case study of a blowing snow SSA event over the Arctic, which was detected by CALIOP on 6 November 2008 and predicted by our blowing snow simulation. Using FLEXPART, we find that the observed aerosol extinction layer originated 2 days earlier over sea ice below $100 \mathrm{~m}$ altitude. We demonstrate that CALIOP detects this blowing snow event below $200 \mathrm{~m}$ altitude with enhanced extinction and a large depolarization ratio, co-located with surface high winds.

Our work suggests that blowing snow emissions are the dominant source of SSA over sea ice covered regions during cold months. As SSA can act as a source of halogens, 
the inclusion of blowing snow in chemical transport models is important in understanding springtime bromine explosions and the resulting ozone and mercury depletion events (Schroeder et al., 1998; Simpson et al., 2007; Steffen et al., 2008; Gilman et al., 2010; Yang et al., 2010). Furthermore, these sea-ice sources of SSA can act as ice nuclei for cloud formation and may increase the downward longwave radiative forcing (Xu et al., 2013). Arctic sea ice has been rapidly changing over the past 30 years, with decreasing sea ice extent and thickness (e.g., Kwok and Rothrock, 2009), a shift towards less MYI and more FYI (Fowler et al., 2004; Maslanik et al., 2007), and a thinning of snow depth in spring (Renner et al., 2014; Blanchard-Wrigglesworth et al., 2015). All these factors are likely to have resulted in an increase in snow salinity on sea ice, hence increasing SSA emissions from blowing snow. In the Southern Hemisphere, sea ice extent is FYI-dominant, and its annual and seasonal trends are more complex, varying in space. Sea ice extent has been increasing over the Ross Sea, but it has been decreasing over the Amundsen-Bellingshausen Sea over the past decades (Turner et al., 2009; Parkinson and Cavalieri, 2012; Stammerjohn et al., 2012). Consequently, this may have resulted in a shift in the spatial pattern of blowing snow SSA emissions, with increased influence over the Ross Sea and reduced influence over the Amundsen-Bellingshausen Sea.

Data availability. The CALIOP L2 data are available at https://doi.org/10.5067/CALIOP/CALIPSO/LID_L2_05kmAProStandard-V4-10 (Winker, 2016). The GEOS-Chem code is available at http://acmg.seas.harvard.edu/geos/ (last access: 8 September 2015; Bey et al., 2001). The GEOS-Chem simulations for this work are available at http://hdl.handle.net/1773/42862 (last access: 13 November 2018).

Supplement. The supplement related to this article is available online at: https://doi.org/10.5194/acp-18-16253-2018-supplement.

Author contributions. JH and LJ designed the study. JH conducted the GEOS-Chem simulations and performed the data analysis. VS conducted the FLEXPART simulations. JH and LJ wrote the paper. All authors discussed the results and contributed to the final paper.

Competing interests. The authors declare that they have no conflict of interest.

Acknowledgements. This work was supported by funding from the NASA Atmospheric Composition Modeling and Analysis Program under award NNX15AE32G. The CALIOP data were obtained from the NASA Langley Research Center - Atmospheric Science Data Center.
Edited by: Paul Zieger

Reviewed by: three anonymous referees

\section{References}

Abram, N. J., Wolff, E. W., and Curran, M. A. J.: A review of sea ice proxy information from polar ice cores, Quaternary Sci. Rev., 79, 168-183, https://doi.org/10.1016/j.quascirev.2013.01.011, 2013.

Alvarez-Aviles, L., Simpson, W. R., Douglas, T. A., Sturm, M., Perovich, D., and Domine, F.: Frost flower chemical composition during growth and its implications for aerosol production and bromine activation, J. Geophys. Res., 113, D21304, https://doi.org/10.1029/2008JD010277, 2008.

Barber, D. G., Reddan, S. P., and Ledrew, E. F.: Statistical Characterization of the Geophysical and Electrical-Properties of Snow on Landfast First-Year Sea-Ice, J. Geophys. Res.-Oceans, 100, 2673-2686, https://doi.org/10.1029/94jc02200, 1995.

Bey, I., Jacob, D. J., Yantosca, R. M., Logan, J. A., Field, B. D., Fiore, A. M., Li, Q., Liu, H. Y., Mickley, L. J., and Schultz, M. G.: Global modeling of tropospheric chemistry with assimilated meteorology: Model description and evaluation, J. Geophys. Res.-Atmos., 106, 23073-23095, https://doi.org/10.1029/2001jd000807, 2001 (data available at: http://acmg.seas.harvard.edu/geos/, last access: 8 September 2015).

Blanchard-Wrigglesworth, E., Farrell, S. L., Newman, T., and Bitz, C. M.: Snow cover on Arctic sea ice in observations and an Earth System Model, Geophys. Res. Lett., 42, 10342-10348, https://doi.org/10.1002/2015GL066049, 2015.

Bond, T. C., Bhardwaj, E., Dong, R., Jogani, R., Jung, S. K., Roden, C., Streets, D. G., and Trautmann, N. M.: Historical emissions of black and organic carbon aerosol from energy-related combustion, 1850-2000, Global Biogeochem. Cy., 21, GB2018, https://doi.org/10.1029/2006gb002840, 2007.

de Leeuw, G., Andreas, E. L., Anguelova, M. D., Fairall, C. W., Lewis, E. R., O’Dowd, C., Schulz, M., and Schwartz, S. E.: Production flux of sea-spray aerosol, Rev. Geophys., 49, RG2001, https://doi.org/10.1029/2010RG000349, 2011.

Di Pierro, M., Jaeglé, L., Eloranta, E. W., and Sharma, S.: Spatial and seasonal distribution of Arctic aerosols observed by the CALIOP satellite instrument (2006-2012), Atmos. Chem. Phys., 13, 7075-7095, https://doi.org/10.5194/acp-137075-2013, 2013.

Domine, F., Sparapani, R., Ianniello, A., and Beine, H. J.: The origin of sea salt in snow on Arctic sea ice and in coastal regions, Atmos. Chem. Phys., 4, 2259-2271, https://doi.org/10.5194/acp4-2259-2004, 2004.

Domine, F., Taillandier, A. S., Simpson, W. R., and Severin, K.: Specific surface area, density and microstructure of frost flowers, Geophys. Res. Lett., 32, L13502, https://doi.org/10.1029/2005GL023245, 2005.

Fischer, H., Siggaard-Andersen, M.L., Ruth, U., Röthlisberger, R., and Wolff, E.: Glacial/interglacial changes in mineral dust and sea-salt records in polar ice cores: Sources, transport, and deposition, Rev. Geophys., 45, RG1002, https://doi.org/10.1029/2005rg000192, 2007.

Fisher, J. A., Jacob, D. J., Travis, K. R., Kim, P. S., Marais, E. A., Chan Miller, C., Yu, K., Zhu, L., Yantosca, R. M., Sul- 
prizio, M. P., Mao, J., Wennberg, P. O., Crounse, J. D., Teng, A. P., Nguyen, T. B., St. Clair, J. M., Cohen, R. C., Romer, P., Nault, B. A., Wooldridge, P. J., Jimenez, J. L., CampuzanoJost, P., Day, D. A., Hu, W., Shepson, P. B., Xiong, F., Blake, D. R., Goldstein, A. H., Misztal, P. K., Hanisco, T. F., Wolfe, G. M., Ryerson, T. B., Wisthaler, A., and Mikoviny, T.: Organic nitrate chemistry and its implications for nitrogen budgets in an isoprene- and monoterpene-rich atmosphere: constraints from aircraft (SEAC4RS) and ground-based (SOAS) observations in the Southeast US, Atmos. Chem. Phys., 16, 5969-5991, https://doi.org/10.5194/acp-16-5969-2016, 2016.

Fountoukis, C. and Nenes, A.: ISORROPIA II: a computationally efficient thermodynamic equilibrium model for $\mathrm{K}^{+}-\mathrm{Ca}^{2+}-\mathrm{Mg}^{2+}-\mathrm{NH}^{4+}-\mathrm{Na}^{+}-\mathrm{SO}_{4}^{2-}-\mathrm{NO}_{3}-\mathrm{Cl}^{-}-\mathrm{H}_{2} \mathrm{O}$ aerosols, Atmos. Chem. Phys., 7, 4639-4659, https://doi.org/10.5194/acp-7-4639-2007, 2007.

Fowler, C., Emery, W. J., and Maslanik, J.: Satellite-derived evolution of Arctic sea ice age: October 1978 to March 2003, IEEE Geosci Remote Sens. Soc. Lett. 1, 71-74, https://doi.org/10.1109/LGRS.2004.824741, 2004.

Geldsetzer, T., Langlois, A., and Yackel, J.: Dielectric properties of brine-wetted snow on first-year sea ice, Cold Reg. Sci. Technol., 58, 47-56, https://doi.org/10.1016/j.coldregions.2009.03.009, 2009.

Gilman, J. B., Burkhart, J. F., Lerner, B. M., Williams, E. J., Kuster, W. C., Goldan, P. D., Murphy, P. C., Warneke, C., Fowler, C., Montzka, S. A., Miller, B. R., Miller, L., Oltmans, S. J., Ryerson, T. B., Cooper, O. R., Stohl, A., and de Gouw, J. A.: Ozone variability and halogen oxidation within the Arctic and sub-Arctic springtime boundary layer, Atmos. Chem. Phys., 10, 1022310236, https://doi.org/10.5194/acp-10-10223-2010, 2010.

Guenther, A. B., Jiang, X., Heald, C. L., Sakulyanontvittaya, T., Duhl, T., Emmons, L. K., and Wang, X.: The Model of Emissions of Gases and Aerosols from Nature version 2.1 (MEGAN2.1): an extended and updated framework for modeling biogenic emissions, Geosci. Model Dev., 5, 1471-1492, https://doi.org/10.5194/gmd-5-1471-2012, 2012.

Hara, K., Osada, K., Yabuki, M., and Yamanouchi, T.: Seasonal variation of fractionated sea-salt particles on the Antarctic coast, Geophys. Res. Lett., 39, L18801, https://doi.org/10.1029/2012GL052761, 2012.

Hara, K., Matoba, S., Hirabayashi, M., and Yamasaki, T.: Frost flowers and sea-salt aerosols over seasonal sea-ice areas in northwestern Greenland during winter-spring, Atmos. Chem. Phys., 17, 8577-8598, https://doi.org/10.5194/acp-178577-2017, 2017.

Huang, J. and Jaeglé, L.: Wintertime enhancements of sea salt aerosol in polar regions consistent with a sea ice source from blowing snow, Atmos. Chem. Phys., 17, 3699-3712, https://doi.org/10.5194/acp-17-3699-2017, 2017.

Jacobi, H. W., Voisin, D., Jaffrezo, J. L., Cozic, J., and Douglas, T. A.: Chemical composition of the snowpack during the 30 OASIS spring campaign 2009 at Barrow, Alaska, J. Geophys. Res., 117, D00R13, https://doi.org/10.1029/2011jd016654, 2012.

Jaeglé, L., Quinn, P. K., Bates, T. S., Alexander, B., and Lin, J.-T.: Global distribution of sea salt aerosols: new constraints from in situ and remote sensing observations, Atmos. Chem. Phys., 11, 3137-3157, https://doi.org/10.5194/acp-11-3137-2011, 2011.
Jourdain, B., Preunkert, S., Cerri, O., Castebrunet, H., Udisti, R., and Legrand, M.: Year-round record of size segregated aerosol composition in central Antarctica (Concordia station): Implications for the degree of fractionation of sea-salt particles, J. Geophys. Res., 113, D14308, https://doi.org/10.1029/2007JD009584, 2008.

Kaleschke, L., Richter, A., Burrows, J., Afe, O., Heygster, G., Notholt, J., Rankin, A. M., Roscoe, H. K., Hollwedel, J., Wagner, T., and Jacobi, H.-W.: Frost flowers on sea ice as a source of sea salt and their influence on tropospheric halogen chemistry, Geophys. Res. Lett., 31, L16114, https://doi.org/10.1029/2004GL020655, 2004.

Klimont, Z., Kupiainen, K., Heyes, C., Purohit, P., Cofala, J., Rafaj, P., Borken-Kleefeld, J., and Schöpp, W.: Global anthropogenic emissions of particulate matter including black carbon, Atmos. Chem. Phys., 17, 8681-8723, https://doi.org/10.5194/acp-178681-2017, 2017.

Krnavek, L., Simpson, W. R., Carlson, D., Dominé, F., Douglas, T. A., and Sturm, M.: The chemical composition of surface snow in the Arctic: examining marine, terrestrial, and atmospheric influence, Atmos. Environ., 50, 349-359, https://doi.org/10.1016/j.atmosenv.2011.11.033, 2012.

Kwok, R. and Rothrock, D.: Decline in Arctic sea ice thickness from submarine and ICESat records: 1958-2008, Geophys. Res. Lett., 36, L15501, https://doi.org/10.1029/2009GL039035, 2009.

Kwok, R. and Cunningham, G. F.: Variability of Arctic sea ice thickness and volume from CryoSat-2, Phil. Trans. R. Soc. A, 373, 20140157, https://doi.org/10.1098/rsta.2014.0157, 2015.

Lewis, E. R. and Schwartz, S. E.: Sea Salt Aerosol Production: Mechanisms, Methods, Measurements, and Models: A Critical Review, American Geophysical Union, Washington, DC, 2004.

Lewis, E. R. and Schwartz, S. E.: Comment on "size distribution of sea-salt emissions as a function of relative humidity", Atmos. Environ., 40, 588-590, 2006.

Li, C., Hsu, N. C., Sayer, A. M., Krotkov, N. A., Fu, J. S., Lamsal, L. N., Lee, J., and Tsay, S.-C.: Satellite observation of pollutant emissions from gas flaring activities near the Arctic, Atmos. Environ., 133, 1-11, https://doi.org/10.1016/j.atmosenv.2016.03.019, 2016.

Li, M., Zhang, Q., Kurokawa, J.-I., Woo, J.-H., He, K., Lu, Z., Ohara, T., Song, Y., Streets, D. G., Carmichael, G. R., Cheng, Y., Hong, C., Huo, H., Jiang, X., Kang, S., Liu, F., Su, H., and Zheng, B.: MIX: a mosaic Asian anthropogenic emission inventory under the international collaboration framework of the MICS-Asia and HTAP, Atmos. Chem. Phys., 17, 935-963, https://doi.org/10.5194/acp-17-935-2017, 2017.

Lin, J.-T. and McElroy, M. B.: Detection from space of a reduction in anthropogenic emissions of nitrogen oxides during the Chinese economic downturn, Atmos. Chem. Phys., 11, 8171-8188, https://doi.org/10.5194/acp-11-8171-2011, 2011.

Lin, S.-J. and Rood, R. B.: Multidimensinal flux-form semi-Lagrangian transport schemes, Mon. Weather Rev., 124, 2046-2070, https://doi.org/10.1175/15200493(1996)124<2046:MFFSLT> 2.0.CO;2, 1996.

Liu, H., Jacob, D. J., Bey, I., and Yantosca, R. M.: Constraints from ${ }^{210} \mathrm{~Pb}$ and ${ }^{7} \mathrm{Be}$ on wet deposition and transport in a global three-dimensional chemical tracer model driven by assimilated meteorological fields, J. Geophys. Res., 106, 1210912128, https://doi.org/10.1029/2000JD900839, 2001. 
Liu, Z. Y., Vaughan, M., Winker, D., Kittaka, C., Getzewich, B., Kuehn, R., Omar, A., Powell, K., Trepte, C., and Hostetler, C.: The CALIPSO Lidar Cloud and Aerosol Discrimination: Version 2 Algorithm and Initial Assessment of Performance, J. Atmos. Ocean. Tech., 26, 1198-1213, https://doi.org/10.1175/2009JTECHA1229.1, 2009.

Mann, G. W., Anderson, P. S., and Mobbs, S. D.: Profile measurements of blowing snow at Halley, Antarctica, J. Geophys. Res., 105, 24491-24508, 2000.

Mao, J., Jacob, D. J., Evans, M. J., Olson, J. R., Ren, X., Brune, W. H., Clair, J. M. St., Crounse, J. D., Spencer, K. M., Beaver, M. R., Wennberg, P. O., Cubison, M. J., Jimenez, J. L., Fried, A., Weibring, P., Walega, J. G., Hall, S. R., Weinheimer, A. J., Cohen, R. C., Chen, G., Crawford, J. H., McNaughton, C., Clarke, A. D., Jaeglé, L., Fisher, J. A., Yantosca, R. M., Le Sager, P., and Carouge, C.: Chemistry of hydrogen oxide radicals (HOx) in the Arctic troposphere in spring, Atmos. Chem. Phys., 10, 58235838, https://doi.org/10.5194/acp-10-5823-2010, 2010.

Mao, J., Fan, S., Jacob, D. J., and Travis, K. R.: Radical loss in the atmosphere from $\mathrm{Cu}-\mathrm{Fe}$ redox coupling in aerosols, Atmos. Chem. Phys., 13, 509-519, https://doi.org/10.5194/acp-13-5092013, 2013.

Martin, S.: A field study of brine drainage and oil entrapment in first-year sea ice, J. Glaciol., 22, 473-502, 1979.

Martin, R. V., Jacob, D. J., Yantosca, R. M., Chin, M., and Ginoux, P.: Global and regional decreases in oxidants from photochemical effects of aerosols, J. Geophys. Res., 108, 4097, https://doi.org/10.1029/2002JD002622, 2003.

Maslanik, J. A., Fowler, C., Stroeve, J., Drobot, S., Zwally, H. J., Yi, D., and Emery, W. J.: A younger, thinner ice cover: increased potential for rapid, extensive ice loss, Geophys. Res. Lett., 34, L24501, https://doi.org/10.1029/2007GL032043, 2007.

Massom, R. A., Eicken, H., Hass, C., Jeffries, M. O., Drinkwater, M. R., Sturm, M., Worby, A. P., Wu, X., Lytle, V. I., Ushio, S., Morris, K., Reid, P. A., Warren, S. G., and Allison, I.: Snow on Antarctic sea ice, Rev. Geophys., 39, 413-445, https://doi.org/10.1029/2000RG000085, 2001.

May, N. W., Quinn, P. K., McNamara, S. M., and Pratt, K. A.: Multiyear study of the dependence of sea salt aerosol on wind speed and sea ice conditions in the coastal Arctic, J. Geophys. Res.-Atmos., 121, 9208-9219, https://doi.org/10.1002/2016JD025273, 2016.

Mundy, C. J., Barber, D. G., and Michel, C.: Variability of snow and ice thermal, physical and optical properties pertinent to sea ice algae biomass during spring, J. Mar. Syst., 58, 107-120, https://doi.org/10.1016/j.jmarsys.2005.07.003, 2005.

Nandan, V., Geldsetzer, T., Yackel, J., Mahmud, M., Scharien, R., Howell, S., King, J., Ricker, R., and Else, B.: Effect of Snow Salinity on CryoSat-2 Arctic First-Year Sea Ice Freeboard Measurements, Geophys. Res. Lett., 44, 10419-10426, https://doi.org/10.1002/2017GL074506, 2017.

Nakawo, M. and Sinha, N. K.: Growth rate and salinity profile of first-year sea ice in the high Arctic, J. Glaciol., 27, 315-330, https://doi.org/10.1017/S0022143000015409, 1981.

Nilsson, E. D., Rannik, U., Swietlicki, E., Leck, C., Aalto, P. P., Zhou, J., and Norman, M.: Turbulent aerosol fluxes over the Arctic Ocean 2, Wind-driven sources from the sea, J. Geophys. Res., 106, 32111-32124, 2001.
Rankin, A. M., Auld, V., and Wolff, E. W.: Frost flowers as a source of fractionated sea salt aerosol in the polar regions, Geophys. Res. Lett., 27, 3469-3472, https://doi.org/10.1029/2000GL011771, 2000.

Renner, A. H., Gerland, S., Haas, C., Spreen, G., Beckers, J. F., Hansen, E., Nicolaus, M., and Goodwin, H.: Evidence of Arctic sea ice thinning from direct observations, Geophys. Res. Lett., 41, 5029-5036, https://doi.org/10.1002/2014GL060369, 2014.

Reynolds, R. W., Rayner, N. A., Smith, T. M., Stokes, D. C., and Wang, W.: An improved in situ and satellite SST analysis for climate, J. Climate, 15, 1609-1625, https://doi.org/10.1175/15200442(2002)015<1609:AIISAS>2.0.CO;2, 2002.

Rienecker, M. M., Suarez, M. J., Gelaro, R., Todling, R., Bacmeister, J., Liu, E., Bosilovich, M. G., Schubert, S. D., Takacs, L., Kim, G.-K., Bloom, S., Junye, C., Collins, D., Conaty, A., da Silva, A., Gu, W., Joiner, J., Koster, R. D., Lucchesi, R., Molod, A., Owens, T., Pawson, S., Pegion, P., Redder, C. R., Reichle, R., Robertson, F. R., Ruddick, A. G., Sienkiewicz, M., and Woollen, J.: MERRA: NASA's modern-era retrospective analysis for research and applications, J. Climate, 24, 3624-3648, https://doi.org/10.1175/JCLI-D-11-00015.1, 2011.

Roscoe, H. K., Brooks, B., Jackson, A. V., Smith, M. H., Walker, S. J., Obbard, R. W., and Wolff, E. W.: Frost flowers in the laboratory: Growth, characteristics, aerosol, and the underlying sea ice, J. Geophys. Res., 116, D12301, https://doi.org/10.1029/2010JD015144, 2011.

Schroeder, W. H., Anlauf, K. G., Barrie, L. A., Lu, J. Y., Steffen, A., Schneeberger, D. R., and Berg, T.: Arctic springtime depletion of mercury, Nature, 394, 331-332, https://doi.org/10.1038/28530, 1998.

Seguin, A. M., Norman, A. L., and Barrie, L.: Evidence of sea ice source in aerosol sulfate loading and size distribution in the Canadian High Arctic from isotopic analysis, J. Geophys. Res.-Atmos., 119, 1087-1096, https://doi.org/10.1002/2013JD020461, 2014.

Seibert, P. and Frank, A.: Source-receptor matrix calculation with a Lagrangian particle dispersion model in backward mode, Atmos. Chem. Phys., 4, 51-63, https://doi.org/10.5194/acp-4-512004, 2004.

Shaw, P. M., Russell, L. M., Jefferson, A., and Quinn, P. K.: Arctic organic aerosol measurements show particles from mixed combustion in spring haze and from frost flowers in winter, Geophys. Res. Lett., 37, L10803, https://doi.org/10.1029/2010GL042831, 2010.

Simpson, W. R., Carlson, D., Hönninger, G., Douglas, T. A., Sturm, M., Perovich, D., and Platt, U.: First-year sea-ice contact predicts bromine monoxide $(\mathrm{BrO})$ levels at Barrow, Alaska better than potential frost flower contact, Atmos. Chem. Phys., 7, 621-627, https://doi.org/10.5194/acp-7-621-2007, 2007.

Slinn, S. A. and Slinn, W. G. N.: Predictions for particle deposition on natural waters, Atmos. Environ., 14, 1013-1016, https://doi.org/10.1016/0004-6981(80)90032-3, 1980.

Stammerjohn, S., Massom, R., Rind, D., and Martinson, D.: Regions of rapid sea ice change: An inter-hemispheric seasonal comparison, Geophys. Res. Lett., 39, L06501, https://doi.org/10.1029/2012GL050874, 2012.

Steffen, A., Douglas, T., Amyot, M., Ariya, P., Aspmo, K., Berg, T., Bottenheim, J., Brooks, S., Cobbett, F., Dastoor, A., Dommergue, A., Ebinghaus, R., Ferrari, C., Gardfeldt, K., Goodsite, M. E., 
Lean, D., Poulain, A. J., Scherz, C., Skov, H., Sommar, J., and Temme, C.: A synthesis of atmospheric mercury depletion event chemistry in the atmosphere and snow, Atmos. Chem. Phys., 8, 1445-1482, https://doi.org/10.5194/acp-8-1445-2008, 2008.

Stohl, A., Hittenberger, M., and Wotawa, G.: Validation of the Lagrangian particle dispersion model FLEXPART against large scale tracer experiment data, Atmos. Environ., 32, 4245-4264, https://doi.org/10.1016/S1352-2310(98)00184-8, 1998.

Stohl, A., Forster, C., Frank, A., Seibert, P., and Wotawa, G.: Technical note: The Lagrangian particle dispersion model FLEXPART version 6.2, Atmos. Chem. Phys., 5, 2461-2474, https://doi.org/10.5194/acp-5-2461-2005, 2005.

Tesche, M., Zieger, P., Rastak, N., Charlson, R. J., Glantz, P., Tunved, P., and Hansson, H.-C.: Reconciling aerosol light extinction measurements from spaceborne lidar observations and in situ measurements in the Arctic, Atmos. Chem. Phys., 14, 78697882, https://doi.org/10.5194/acp-14-7869-2014, 2014.

Travis, K. R., Jacob, D. J., Fisher, J. A., Kim, P. S., Marais, E. A., Zhu, L., Yu, K., Miller, C. C., Yantosca, R. M., Sulprizio, M. P., Thompson, A. M., Wennberg, P. O., Crounse, J. D., St. Clair, J. M., Cohen, R. C., Laughner, J. L., Dibb, J. E., Hall, S. R., Ullmann, K., Wolfe, G. M., Pollack, I. B., Peischl, J., Neuman, J. A., and Zhou, X.: Why do models overestimate surface ozone in the Southeast United States?, Atmos. Chem. Phys., 16, 1356113577, https://doi.org/10.5194/acp-16-13561-2016, 2016.

Turner, J., Comiso, J. C., Marshall, G. J., Lachlan-Cope, T. A., Bracegirdle, T., Maksym, T., Meredith, M. P., Wang, Z., and Orr, A.: Non-annular atmospheric circulation change induced by stratospheric ozone depletion and its role in the recent increase of Antarctic sea ice extent, Geophys. Res. Lett., 36, L08502, https://doi.org/10.1029/2009GL037524, 2009.

Obbard, R. W., Roscoe, H. K., Wolff, E. W., and Atkinson, H. M.: Frost flower surface area and chemistry as a function of salinity and temperature, J. Geophys. Res., 114, D20305, https://doi.org/10.1029/2009JD012481, 2009.

Olivier, J. G. J. and Berdowski, J. J. M.: Global emissions sources and sinks, in: The Climate System, edited by: Berdowski, J., Guicherit, R., and Heij, B. J., A.A. Balkema Publishers/Swets \& Zeitlinger Publishers, Lisse, the Netherlands, 33-78, 2001.

Omar, A. H, Winker, D. M., Kittaka, C., Vaughan, M. A., Liu, Z. Y., Hu, Y. X., Trepte, C. R., Rogers, R. R., Ferrare, R. A., Lee, K. P., Kuehn, R. E., and Hostetler, C. A.: The CALIPSO automated aerosol classification and lidar ratio selection algorithm, J. Atmos. Ocean. Tech., 26, 1994-2014, https://doi.org/10.1175/2009JTECHA1231.1, 2009.

Palm, S. P., Yang, Y. K., Spinhirne, J. D., and Marshak, A.: Satellite remote sensing of blowing snow properties over Antarctica, J. Geophys. Res.-Atmos., 116, 1-16, https://doi.org/10.1029/2011jd015828, 2011.

Palm, S. P., Kayetha, V., Yang, Y., and Pauly, R.: Blowing snow sublimation and transport over Antarctica from 11 years of CALIPSO observations, The Cryosphere, 11, 2555-2569, https://doi.org/10.5194/tc-11-2555-2017, 2017.

Parkinson, C. L. and Cavalieri, D. J.: Antarctic sea ice variability and trends, 1979-2010, The Cryosphere, 6, 871-880, https://doi.org/10.5194/tc-6-871-2012, 2012.

Perovich, D. K. and Richter-Menge, J. A.: Surface characteristics of lead ice, J. Geophys. Res., 99, 16341-16350, https://doi.org/10.1029/94JC01194, 1994.
Pye, H. O. T., Liao, H., Wu, S., Mickley, L. J., Jacob, D. J., Henze, D. K., and Seinfeld, J. H.: Effect of changes in climate and emissions on future sulfate-nitrate-ammonium aerosol levels in the United States, J. Geophys. Res., 114, D01205, https://doi.org/10.1029/2008JD010701, 2009.

Udisti, R., Dayan, U., Becagli, S., Busetto, M., Frosini, D., Legrand, M., Lucarelli, F., Preunkert, S., Severi, M., Traversi, R., and Vitale, V.: Sea spray aerosol in central Antarctica. Present atmospheric behaviour and implications for paleoclimatic reconstructions, Atmos. Environ., 52, 109-120, https://doi.org/10.1016/j.atmosenv.2011.10.018, 2012.

van der Werf, G. R., Randerson, J. T., Giglio, L., Collatz, G. J., Mu, M., Kasibhatla, P. S., Morton, D. C., DeFries, R. S., Jin, Y., and van Leeuwen, T. T.: Global fire emissions and the contribution of deforestation, savanna, forest, agricultural, and peat fires (1997-2009), Atmos. Chem. Phys., 10, 11707-11735, https://doi.org/10.5194/acp-10-11707-2010, 2010.

van Donkelaar, A., Martin, R. V., Leaitch, W. R., Macdonald, A. M., Walker, T. W., Streets, D. G., Zhang, Q., Dunlea, E. J., Jimenez, J. L., Dibb, J. E., Huey, L. G., Weber, R., and Andreae, M. O.: Analysis of aircraft and satellite measurements from the Intercontinental Chemical Transport Experiment (INTEX-B) to quantify long-range transport of East Asian sulfur to Canada, Atmos. Chem. Phys., 8, 2999-3014, https://doi.org/10.5194/acp-8-29992008, 2008.

Wagenbach, D., Ducroz, F., Mulvaney, R., Keck, L., Minikin, A., Legrand, M., Hall, J. S., and Wolff, E. W.: Sea-salt aerosol in coastal Antarctic regions, J. Geophys. Res., 103, 10961-10974, https://doi.org/10.1029/97JD01804, 1998.

Wang, Y., Jacob, D. J., and Logan, J. A.: Global simulation of tropospheric $\mathrm{O}_{3}-\mathrm{NO}_{x}$-hydrocarbon chemistry, 1 . Model formulation, J. Geophys. Res., 103, 10713-10726, https://doi.org/10.1029/98JD00158, 1998.

Wang, Q., Jacob, D. J., Fisher, J. A., Mao, J., Leibensperger, E. M., Carouge, C. C., Le Sager, P., Kondo, Y., Jimenez, J. L., Cubison, M. J., and Doherty, S. J.: Sources of carbonaceous aerosols and deposited black carbon in the Arctic in winter-spring: implications for radiative forcing, Atmos. Chem. Phys., 11, 1245312473, https://doi.org/10.5194/acp-11-12453-2011, 2011.

Warren, S. G., Rigor, I. G., Untersteiner, N., Radionov, V. F., Bryazgin, N. N., Aleksandrov, Ye. I., and Colony, R.: Snow depth on Arctic sea ice, J. Climate, 12, 1814-1829, 1999.

Weeks, W. F. and Ackley, S. F.: The growth, structure and properties of sea ice, 9-164, Plenum Press, New York, 1986.

Weeks, W. F. and Lee O. S.: Observations on the physical properties of sea-ice at Hopedale, Labrador, Arctic, 11, 135-155, https://doi.org/10.14430/arctic3740, 1958.

Weller, R., Woltjen, J., Piel, C., Resenberg, R., Wagenbach, D., Konig-Langlo, G., and Kriews, M.: Seasonal variability of crustal and marine trace elements in the aerosol at Neumayer station, Antarctica, Tellus, 60, 742-752, https://doi.org/10.1111/j.16000889.2008.00372.x, 2008

Wesely, M. L.: Parameterization of surface resistance to gaseous dry deposition in regional-scale numerical models, Atmos. Environ., 23, 1293-1304, https://doi.org/10.1016/0004-6981(89)90153-4, 1989.

Winker, D.: CALIPSO LID L2 Standard HDF FileVersion 4.10, NASA Langley Research Center Atmospheric Science Data Center DAAC, 
https://doi.org/10.5067/CALIOP/CALIPSO/LID_L2_05kmAProStandard-V4-10, 2016.

Winker, D. M., Vaughan, M. A., Omar, A., Hu, Y., and Powell, J. A.: Overview of the CALIPSO Mission and CALIOP Data Processing Algorithms, J. Atmos. Ocean. Tech., 26, 2310-2323, https://doi.org/10.1175/2009JTECHA1281.1, 2009.

Winker, D. M., Tackett, J. L., Getzewich, B. J., Liu, Z., Vaughan, M. A., and Rogers, R. R.: The global 3-D distribution of tropospheric aerosols as characterized by CALIOP, Atmos. Chem. Phys., 13, 3345-3361, https://doi.org/10.5194/acp-133345-2013, 2013.

Wolff, E. W., Fischer, H., Fundel, F., Ruth, U., Twarloh, B., Littot, G. C., Mulvaney, R., Rothlisberger, R., de Angelis, M., Boutron, C. F., Hansson, M., Jonsell, U., Hutterli, M. A., Bigler, M., Lambeck, K., Kaufmann, P., Stauffer, B., Stocker, T. F., Steffensen, J. P., Siggaard-Andersen, M. L., Udisti, R., Becagli, S., Castellano, E., Severi, M., Wagenbach, D., Barbante, C., Gabrielli, P., and Gaspari, V.: Southern Ocean sea-ice extent, productivity and iron flux over the past eight glacial cycles, Nature, 440, 491-496, https://doi.org/10.1038/nature04614, 2006.

Worby, A. P., Massom, R. A., Allison, I., Lytle, V. I., and Heil, P.: East Antarctic sea ice: A review of its structure, properties and drift, Antarctic sea ice: physical processes, interactions and variability, 41-67, 1998.

Xu, L., Russell, L. M., Somerville, R. C. J., and Quinn, P. K.: Frost flower aerosol effects on Arctic wintertime longwave cloud radiative forcing, J. Geophys. Res.-Atmos., 118, 13282-13291, https://doi.org/10.1002/2013JD020554, 2013.
Xu, J.-W., Martin, R. V., Morrow, A., Sharma, S., Huang, L., Leaitch, W. R., Burkart, J., Schulz, H., Zanatta, M., Willis, M. D., Henze, D. K., Lee, C. J., Herber, A. B., and Abbatt, J. P. D.: Source attribution of Arctic black carbon constrained by aircraft and surface measurements, Atmos. Chem. Phys., 17, 1197111989, https://doi.org/10.5194/acp-17-11971-2017, 2017.

Yang, X., Pyle, J. A., and Cox, R. A.: Sea salt aerosol production and bromine release: Role of snow on sea ice, Geophys. Res. Lett., 35, L16815, https://doi.org/10.1029/2008GL034536, 2008.

Yang, X., Pyle, J. A., Cox, R. A., Theys, N., and Van Roozendael, M.: Snow-sourced bromine and its implications for polar tropospheric ozone, Atmos. Chem. Phys., 10, 7763-7773, https://doi.org/10.5194/acp-10-7763-2010, 2010.

Yang, X., Nedela, V., Runštuk, J., Ondrušková, G., Krausko, J., Vetráková, L., and Heger, D.: Evaporating brine from frost flowers with electron microscopy and implications for atmospheric chemistry and sea-salt aerosol formation, Atmos. Chem. Phys., 17, 6291-6303, https://doi.org/10.5194/acp-176291-2017, 2017.

Zender, C. S.: Mineral Dust Entrainment and Deposition (DEAD) model: Description and 1990s dust climatology, J. Geophys. Res., 108, 4416, https://doi.org/10.1029/2002JD002775, 2003.

Zhang, L., Gong, S., Padro, J., and Barrie, L.: A size-segregated particle dry deposition scheme for an atmospheric aerosol module, Atmos. Environ., 35, 549-560, https://doi.org/10.1016/S13522310(00)00326-5, 2001. 